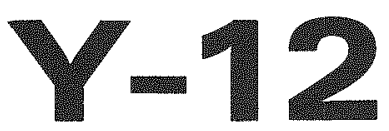

OAK RIDGE

$\mathrm{Y}-12$

PLANT

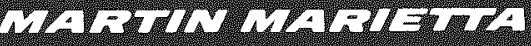

CHESTNUT RIDGE BORROW AREA

WASTE PILE

WORK PLAN

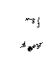

Robert Johnson

Environmental Management Department

Prepared By

Science Applications International Corporation for the

Oak Ridge Y-12 Plant

Oak Ridge, Tennessee 37831 managed by

Martin Marietta Energy Systems, Inc. operated by

U.S. Department of Energy

under Contract No. DE-AC05-840R214

MANAGED BY

MARTIN MARIETTA ENERGY SYSTEMS, INC.

FOR THE UNTED STATES

DEPARTMENT OF ENERGY 


\section{DISCLAIMER}

This report was prepared as an account of work sponsored by an agency of the United States Government. Neither the United States Government nor any agency Thereof, nor any of their employees, makes any warranty, express or implied, or assumes any legal liability or responsibility for the accuracy, completeness, or usefulness of any information, apparatus, product, or process disclosed, or represents that its use would not infringe privately owned rights. Reference herein to any specific commercial product, process, or service by trade name, trademark, manufacturer, or otherwise does not necessarily constitute or imply its endorsement, recommendation, or favoring by the United States Government or any agency thereof. The views and opinions of authors expressed herein do not necessarily state or reflect those of the United States Government or any agency thereof. 


\section{DISCLAIMER}

Portions of this document may be illegible in electronic image products. Images are produced from the best available original document. 


\title{
CHESTNUT RIDGE BORROW AREA \\ WASTE PILE \\ WORK PLAN
}

Robert Johnson

Environmental Management Department

\author{
Prepared By \\ Science Applications International Corporation \\ for the \\ Oak Ridge Y-12 Plant \\ Oak Ridge, Tennessee 37831 \\ managed by \\ Martin Marietta Energy Systems, Inc. \\ operated by \\ U.S. Department of Energy \\ under Contract No. DE-AC05-840R214
}




\section{TABLE OF CONTENTS}

FIGURES $\ldots \ldots \ldots \ldots \ldots \ldots \ldots \ldots \ldots \ldots \ldots \ldots \ldots \ldots \ldots \ldots \ldots \ldots$ vi

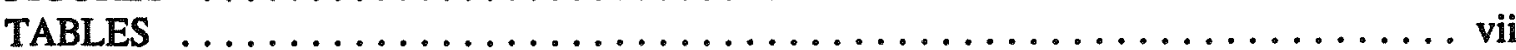

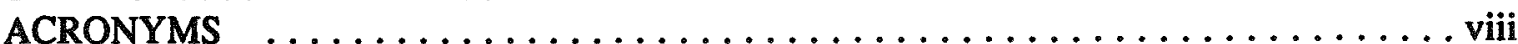

EXECUTIVE SUMMARY $\ldots \ldots \ldots \ldots \ldots \ldots \ldots \ldots \ldots \ldots \ldots \ldots \ldots \ldots$

1. INTRODUCTION $\ldots \ldots \ldots \ldots \ldots \ldots \ldots \ldots \ldots \ldots \ldots \ldots \ldots \ldots$

1.1 OBJECTIVES AND SCOPE OF PLAN $\ldots \ldots \ldots \ldots \ldots \ldots \ldots$

1.2 GENERAL FACILITY INFORMATION $\ldots \ldots \ldots \ldots \ldots \ldots \ldots$

1.3 SITE-SPECIFIC BACKGROUND INFORMATION $\ldots \ldots \ldots \ldots \ldots 3$

1.4 QUALITY ASSURANCE/QUALITY CONTROL ........... 3

2. SITE INVESTIGATION SAMPLING PLAN $\ldots \ldots \ldots \ldots \ldots \ldots \ldots \ldots$

2.1 SAMPLING PLAN SUMMARY $\ldots \ldots \ldots \ldots \ldots \ldots \ldots \ldots$

2.2 SAMPLING AND DATA QUALITY OBJECTIVES $\ldots \ldots \ldots \ldots \ldots 5$

2.2.1 Evaluation of Existing Data ................. 5

2.2.2 Data Quality, Objectives, and Uses $\ldots \ldots \ldots \ldots \ldots$

2.2.3 Analytical Methods and Detection

Limits . . . . . . . . . . . . . . . . . . . . 10

2.2.4 Statistical Evaluation $\ldots \ldots \ldots \ldots \ldots \ldots \ldots \ldots \ldots \ldots$

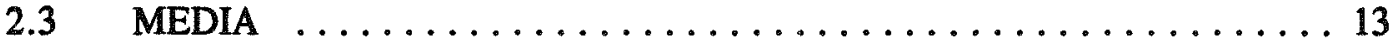

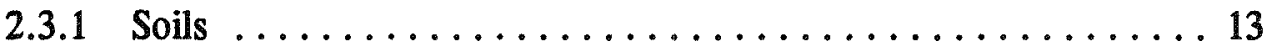

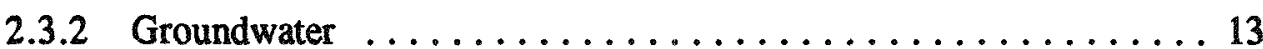

2.3 .3 Surface Water $\ldots \ldots \ldots \ldots \ldots \ldots \ldots \ldots \ldots \ldots \ldots \ldots \ldots$

2.3.4 Ambient Air ....................... 14

$2.4 \quad$ FIELD SAMPLING PLAN $\ldots \ldots \ldots \ldots \ldots \ldots \ldots \ldots \ldots \ldots$

2.4.1 Soil Sampling Procedure $\ldots \ldots \ldots \ldots \ldots \ldots \ldots \ldots \ldots \ldots \ldots$

2.4.2 Sample Volumes and Container $\ldots \ldots \ldots \ldots \ldots \ldots \ldots \ldots$

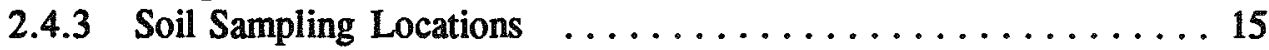

2.4.4 Sample Preservation, Packaging, and

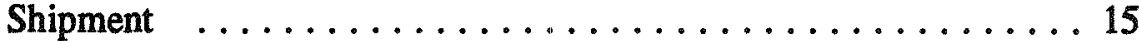

2.4 .5 Field QA/QC Samples $\ldots \ldots \ldots \ldots \ldots \ldots \ldots \ldots \ldots \ldots \ldots$

2.4.6 Equipment Decontamination Procedures $\ldots \ldots \ldots \ldots \ldots 18$

2.5 SAMPLE DOCUMENTATION/HANDLING $\ldots \ldots \ldots \ldots \ldots \ldots$

2.5.1 Sample Identification Numbers $\ldots \ldots \ldots \ldots \ldots . \ldots \ldots$ 
TABLE OF CONTENTS (cont.)

Page

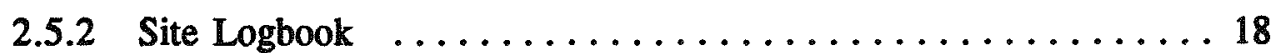

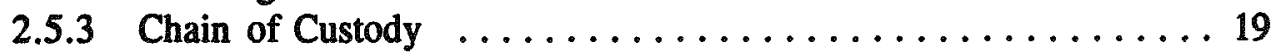

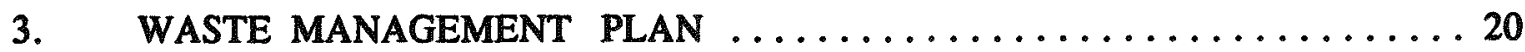

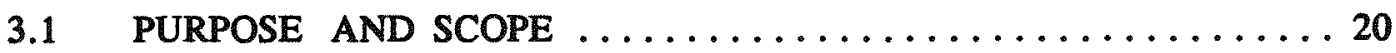

3.2 ROLES AND RESPONSIBILITIES ................ 20

3.2.1 Energy Systems (Y-12 Waste Management

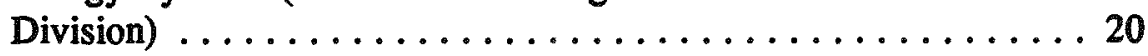

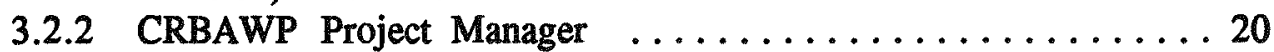

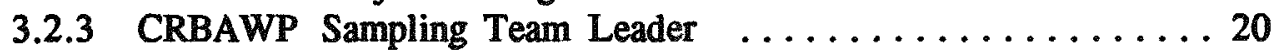

3.2.4 CRBAWP Sampling Team Members .............. 20

3.3 WASTE GENERATION $\ldots \ldots \ldots \ldots \ldots \ldots \ldots \ldots \ldots \ldots \ldots \ldots$

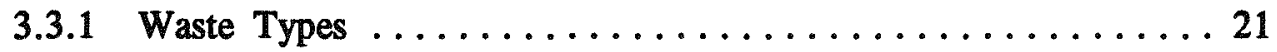

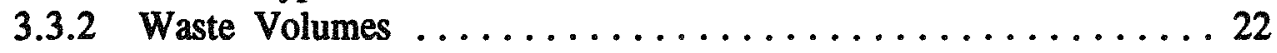

3.4 WASTE HANDLING AND DISPOSITION $\ldots \ldots \ldots \ldots \ldots \ldots 22$

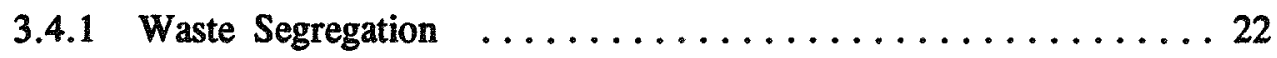

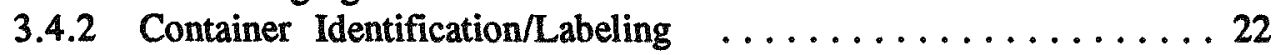

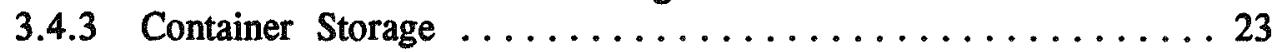

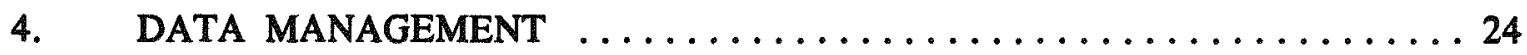

4.1 DATA STRUCTURE AND TYPE $\ldots \ldots \ldots \ldots \ldots \ldots \ldots$

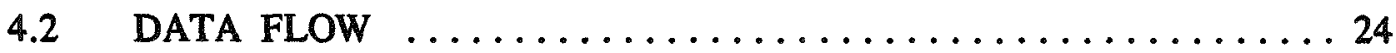

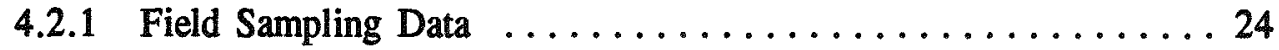

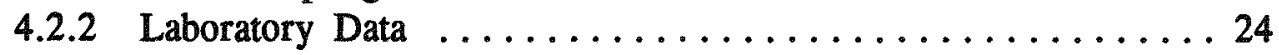

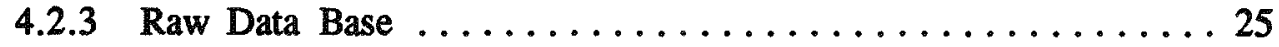

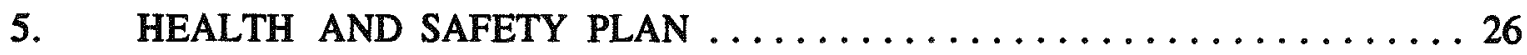

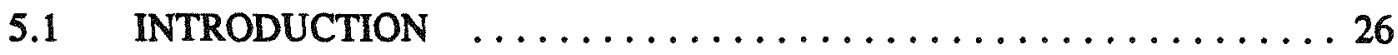

5.2 SITE HAZARD DESCRIPTION $\ldots \ldots \ldots \ldots \ldots \ldots \ldots \ldots \ldots$

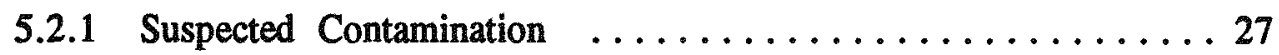

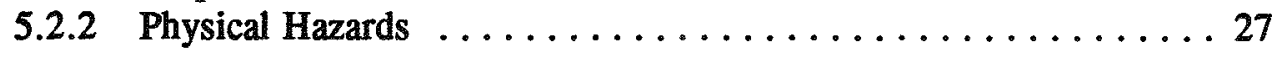

5.3 SITE HAZARD EVALUATION $\ldots \ldots \ldots \ldots \ldots \ldots \ldots \ldots$

91-067/0991 iv 


\section{TABLE OF CONTENTS (cont.)}

Page

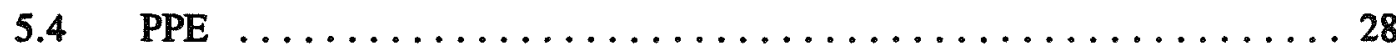

5.4 .1 Level Determination $\ldots \ldots \ldots \ldots \ldots \ldots \ldots \ldots \ldots \ldots \ldots$

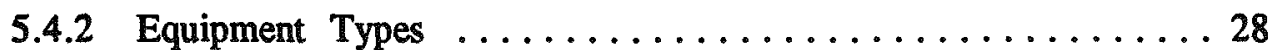

5.5 ENVIRONMENTAL MONITORING $\ldots \ldots \ldots \ldots \ldots \ldots \ldots \ldots \ldots$

5.5 .1 Chemical Monitoring ..................... 28

5.5 .2 Radiological Monitoring . . . . . . . . . . . . . . . 29

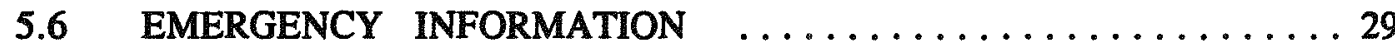

5.6 .1 Contingency Plan ....................... 29

5.6.2 Emergency Contacts and Reporting Requirements ....... 30

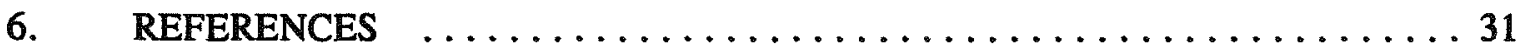

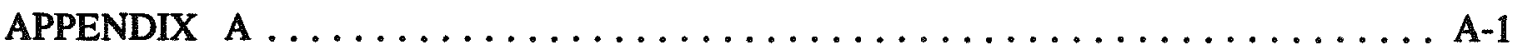

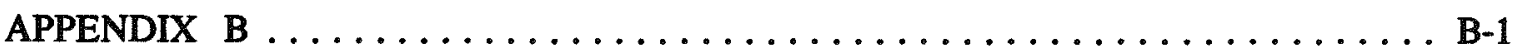




\section{FIGURES}

Page

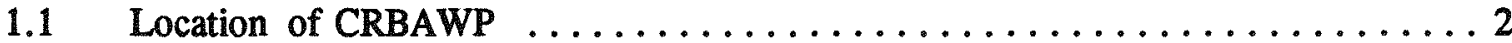

1.2 CRBAWP schematic layout $\ldots \ldots \ldots \ldots \ldots \ldots \ldots \ldots \ldots \ldots$

2.1 Remediated areas of the Oak Ridge Civic Center $\ldots \ldots \ldots \ldots \ldots \ldots \ldots$

2.2 Mercury concentrations at Civic Center fitness track and playground before remediation $\ldots \ldots \ldots \ldots \ldots \ldots \ldots \ldots$

2.3 Mercury concentrations near Oak Ridge Municipal Building before remediation $\ldots \ldots \ldots \ldots \ldots \ldots \ldots \ldots \ldots \ldots$

2.4 Distribution of mercury concentrations in areas prior to remediation at Oak Ridge Civic Center $\ldots \ldots \ldots \ldots \ldots \ldots$

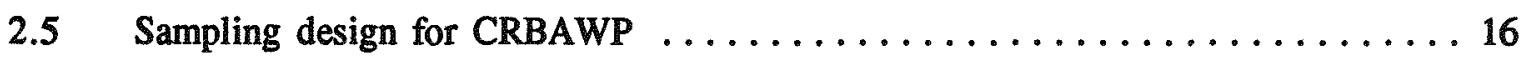




\section{TABLES}

Page

2.1 Analytical methods and detection limits. ............... 11

2.2 Sample apportionment $\ldots \ldots \ldots \ldots \ldots \ldots \ldots \ldots \ldots \ldots \ldots \ldots \ldots$ 


\section{ACRONYMS}

$\mathrm{CDB}$

CERCLA

CRBAWP

DMC

DOE

EFPC

Energy Systems

PCB

PPE

PSS

PVC

QAPP

QA/QC

RCRA

RI

SAS

SHSO

TCLP consolidated data base

Comprehensive Environmental Response, Compensation, and Liability Act

Chestnut Ridge Borrow Area Waste Pile

Data Management Coordinator

Department of Energy

East Fork Poplar Creek

Martin Marietta Energy Systems, Inc.

Polychlorinated Biphenyl

Personal Protective Equipment

Plant Shift Superintendent

Polyvinyl Chloride

Quality Assurance Project Plan

Quality Assurance/Quality Control

Resource Conservation and Recovery Act

Remedial Investigation

Statistical Analysis System

Site Health and Safety Officer

Toxicity Characteristic Leaching Procedure 


\section{EXECUTIVE SUMMARY}

The U.S. Department of Energy (DOE), through its contractor Martin Marietta Energy Systems, Inc., has constructed a storage facility, the Chestnut Ridge Borrow Area Waste Pile (CRBAWP), for mercury-contaminated soil excavated from the Oak Ridge Civic Center properties and the Oak Ridge Sewer Line Beltway. Excavation of the soil from the Civic Center began in September 1984 and was completed in early 1985. Similar soils from other areas of the city were added to the pile until 1987 . Approximately $3000 \mathrm{yd}^{3}$ are stored at the present time. An Interim Status RCRA permit was initially sought for this facility. Samples from the waste pile passed the Extraction Procedure Toxicity Test (EP Tox). The Tennessee Department of Health and Environment (now the Tennessee Department of ConservationTDC) denied the permit based on their conclusion that the waste was not a RCRA-regulated waste. On September 25, 1990 the Toxicity Characteristic Leaching Procedure (TCLP) superseded the EP Tox test. TCLP tests are now proposed to satisfy a request by TDC and to make a final determination of the nature of the soils in order to close the CRBAWP as a solid waste disposal facility under Tennessee State rule 1200-1-7-.04.

The objectives of this work plan are to summarize existing site information and detail actions necessary to sample and characterize soils from the waste pile as hazardous or nonhazardous per the Toxicity Characteristic Leaching Procedure (TCLP). Within the scope of this plan, a site investigation will be discussed; a field sampling plan will be described in terms of sampling locations, procedures, and quality assurance; and ancillary activities such as waste management, data management, and health and safety will be outlined. 


\section{INTRODUCTION}

The U.S. Department of Energy (DOE), through its contractor Martin Marietta Energy Systems, Inc., has constructed a storage facility, the Chestnut Ridge Borrow Area Waste Pile (CRBAWP), for mercury-contaminated soil excavated from the Oak Ridge Civic Center properties and the Oak Ridge Sewer Line Beltway. Excavation of the soil from the Civic Center began in September 1984 and was completed in early 1985. Similar soils from other areas of the city were added to the pile until 1987. Approximately $3000 \mathrm{yd}^{3}$ are stored at the present time. An Interim Status RCRA permit was initially sought for this facility. Samples from the waste pile passed the Extraction Procedure Toxicity Test (EP Tox). The Tennessee Department of Health and Environment (now the Tennessee Department of ConservationTDC) denied the permit based on their conclusion that the waste was not a RCRA-regulated waste. On September 25, 1990 the Toxicity Characteristic Leaching Procedure (TCLP) superseded the EP Tox test. TCLP tests are now proposed to satisfy a request by TDC and to make a final determination of the nature of the soils in order to close the CRBAWP as a solid waste disposal facility under Tennessee State rule 1200-1-7-.04.

\subsection{OBJECTIVES AND SCOPE OF PLAN}

The objectives of this work plan are to summarize existing site information and detail actions necessary to sample and characterize soils from the waste pile as hazardous or nonhazardous per the Toxicity Characteristic Leaching Procedure (TCLP) (40 CFR 261). Within the scope of this plan, a site investigation will be discussed; a field sampling plan will be described in terms of sampling locations, procedures, and quality assurance; and ancillary activities such as waste management, data management, and health and safety will be outlined.

\subsection{GENERAL FACILITY INFORMATION}

The DOE Y-12 Plant (Figure 1.1) is located at the eastern end of Bear Creek Valley immediately adjacent to the city of Oak Ridge. It is bounded to the north by Pine Ridge and to the south by Chestnut Ridge. The CRBAWP lies on Chestnut Ridge south of the South Patrol Road within the Y-12 Plant buffer zone. Soils contained within the CRBAWP were excavated during the remediation of the Oak Ridge Civic Center and of portions of the Sewer Line Beltway. Remediation was necessary due to the placement on these sites of mercurycontaminated topsoils obtained from the East Fork Poplar Creek (EFPC) floodplain. This contamination derived from activities within the Y-12 Plant, which contributed primarily mercury and other metals, but possibly organic compounds as well, to the EFPC watershed. DOE is presently proceeding with a remedial investigation of EFPC under the Comprehensive Environmental Response, Compensation, and Liability Act (CERCLA) and the Resource Conservation and Recovery Act (RCRA). 


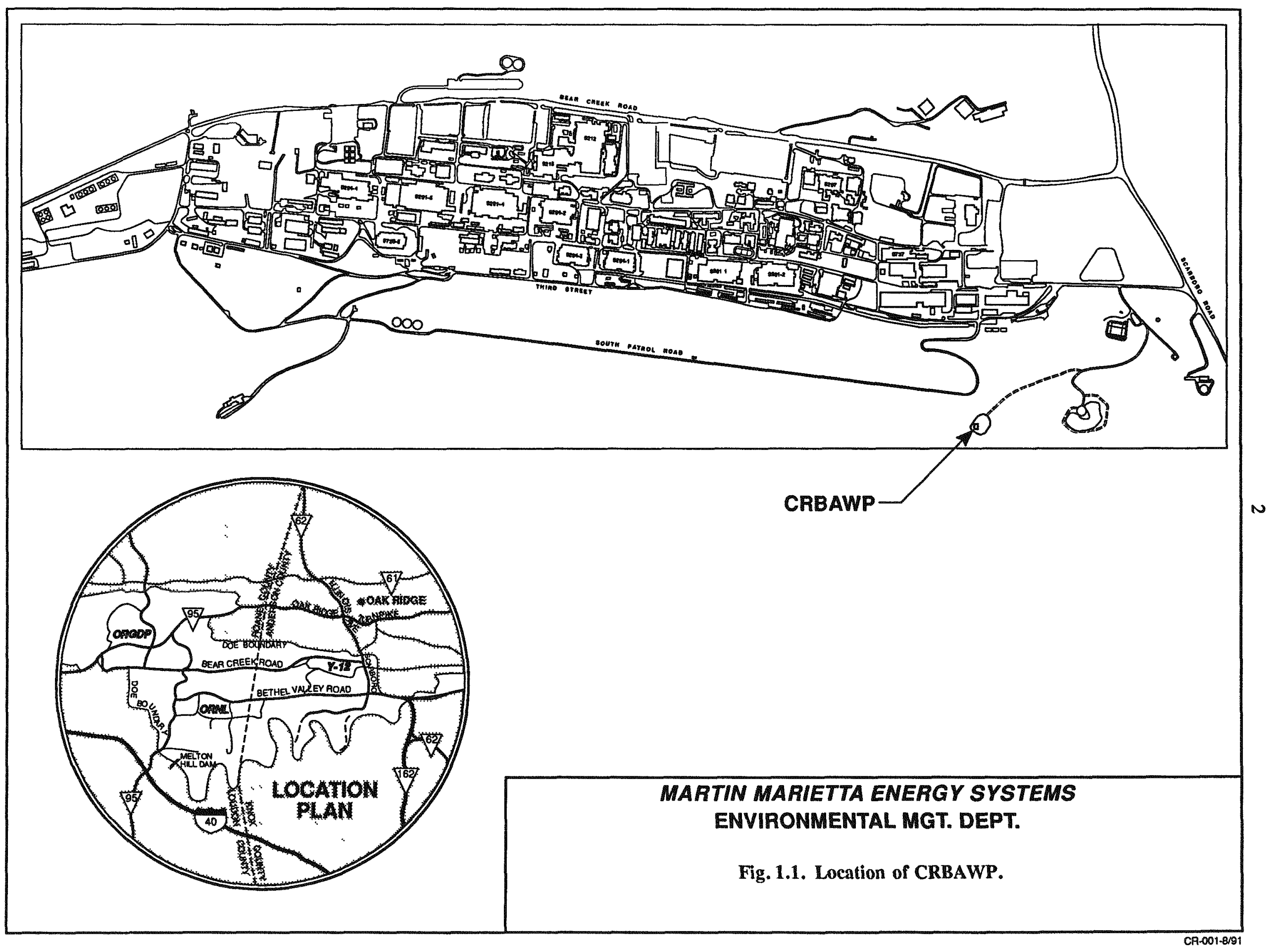




\subsection{SITE-SPECIFIC BACKGROUND INFORMATION}

The CRBAWP is located on the Lovell Quadrangle (138NW) at latitude $84^{\circ} 14^{\prime} 23^{\prime \prime}$ and longitude $35^{\circ} 59^{\prime} 14^{\prime \prime}$. Access is provided by the East Portal Road and the South Patrol Road. The excavated pit is approximately 200 by $70 \mathrm{ft}$ and 10- to 12-ft deep (Figure 1.2). The bottom of the pit was graded and sloped to provide positive drainage and diversion channels and ditches were constructed to intercept and divert surface runoff (Lutz, 1990).

A polyvinyl chloride (PVC) liner was placed on the bottom and walls of the pit. Soil was delivered by truck (approximately $8 \mathrm{yd}^{3}$ per load) and spread and compacted after each load. A plastic liner was placed on top of the pile to restrict infiltration of water. Approximately $60 \%$ of the existing trench and $40 \%$ of the available land has been used to date (Fee, 1990).

\subsection{QUALITY ASSURANCE/QUALITYCONTROL}

Strict quality assurance/quality control (QA/QC) procedures will be adhered to during the sampling of CRBAWP. General QA/QC requirements have been specified in the RCRA Facility Investigation Plan - General Document, Volume II: Quality Assurance Project Plan (QAPP) (Wiggins, 1988a), the Environmental Surveillance Procedures, Quality Control Program (Energy Systems, 1988), and the RCRA Facility Investigation Plan, General Document, Volume III: Data Management Plan (Wiggins, 1988b). Other QA/QC requirements will be set forth in the text of the sampling plan. 

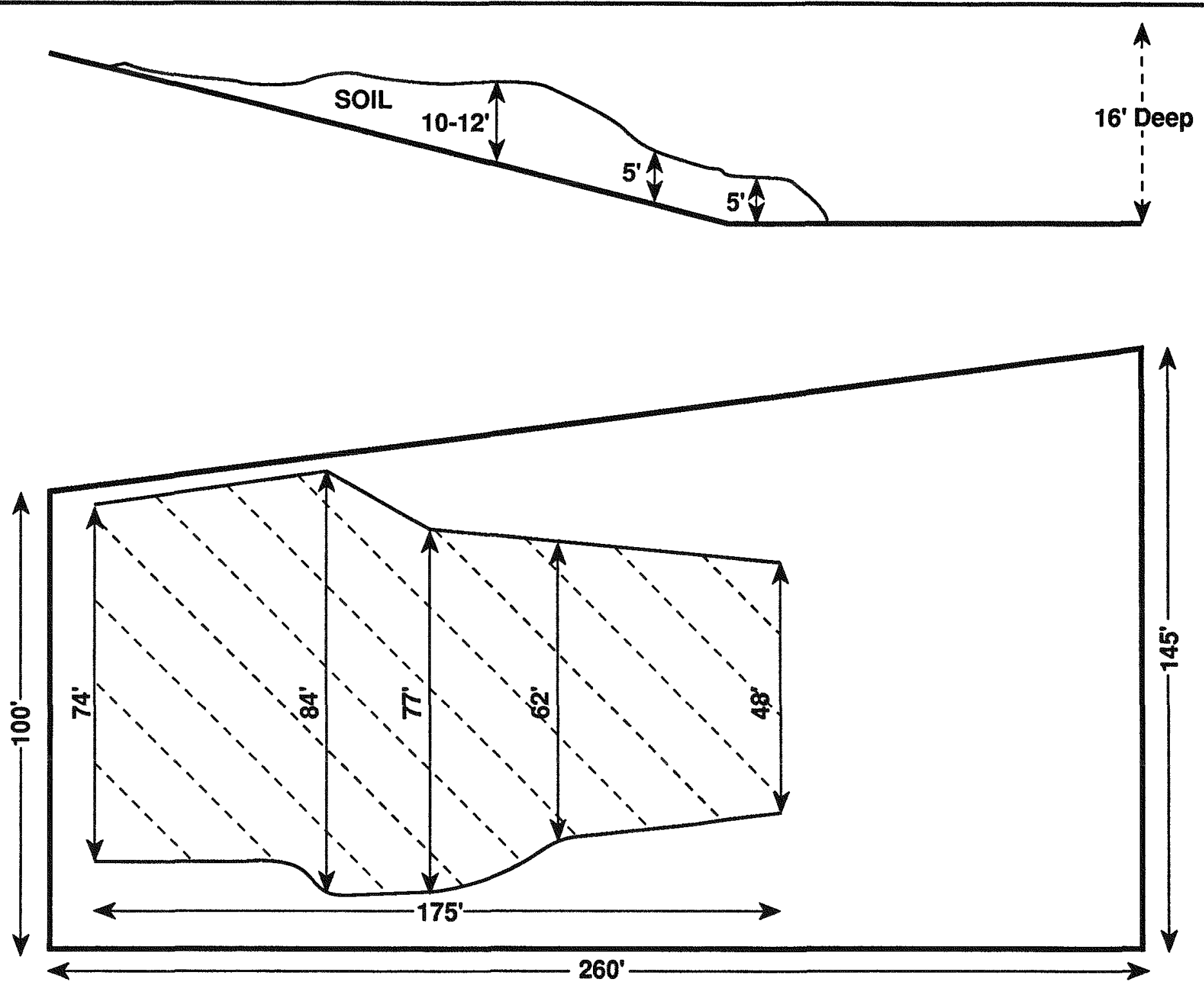

MARTIN MARIETTA ENERGY SYSTEMS

ENVIRONMENTAL MGT. DEPT.

Fig. 1.2. CRBAWPschematic layout. 


\section{SITE INVESTIGATION SAMPLING PLAN}

\subsection{SAMPLING PLAN SUMMARY}

The intent of this sampling plan will be to guide the field activities to acquire a sufficient number of samples for TCLP, uranium, and PCB analysis to characterize the soils within the CRBAWP. This plan is not intended to outline a site investigation in the usual sense, given that the materials in the pile are distributed randomly within the confines of the borrow pit. The spatial distribution of the contaminants within the waste pile is not a result of a deterministic or physical process; therefore, a characterization of the spatial distribution of contaminants -within the waste pile is not necessary to make a proper determination concerning the hazardous or nonhazardous nature of the waste materials. Nonetheless, a proper characterization will consist of obtaining samples throughout the waste pile to mimic the entire distribution of contaminant concentrations.

As a first step, the historical data were reviewed for the Oak Ridge Civic Center site. The areas from which soil was removed to Chestnut Ridge were identified and the analytical values for mercury for these areas were compiled to determine a contaminant distribution. Analytical methods are noted for each component of the TCLP requirement as well as for those previously identified in the soils for this particular site. Sample locations and field methods are identified for acquiring the samples for TCLP; QA/QC requirements are also cited.

\subsection{SAMPLING AND DATA QUALITY OBJECTIVES}

\subsubsection{Evaluation of Existing Data}

Oak Ridge Associated Universities analytical data were reviewed for three areas from which soil was excavated and sent to CRBAWP. The cleanup procedure for the Civic Center was to remediate areas containing total mercury $>100 \mathrm{ppm}$ down to a concentration $<12$ ppm. However, areas of $<100 \mathrm{ppm}$ were not remediated (Hill, 1990). Within the inaccuracies of the given coordinate system for sample locations, results were compiled for various sites from the fitness track area, playground area, and Municipal Building area (Figure 2.1). In total, 551 samples were subjected to mercury analysis (see Figures 2.2 and 2.3 for plot of location and concentrations of mercury) and a select group of others to multielement analyses. The total mercury concentrations range from 0.05 to $460 \mathrm{ppm}$ with a median value of $75.8 \mathrm{ppm}$ (standard deviation $=68.2 \mathrm{ppm}$ ). The frequency of values demonstrates a log-normal distribution (Figure 2.4) with the majority of samples below 25 $\mathrm{ppm}$. It is this range of total mercury concentrations in the soils from which the extract will be obtained by the TCLP. The results of these TCLP analyses will be compared to current regulatory limits (40 CFR Part 261). Previous extraction procedure toxicity tests demonstrated the waste to be nonhazardous (Sleeman, 1990). As a basis for expected results, a sample (BR0199019) from the EFPC remedial investigation (RI) had analytical results for both TCLP and total metals. Even though total metal concentrations were relatively high, 


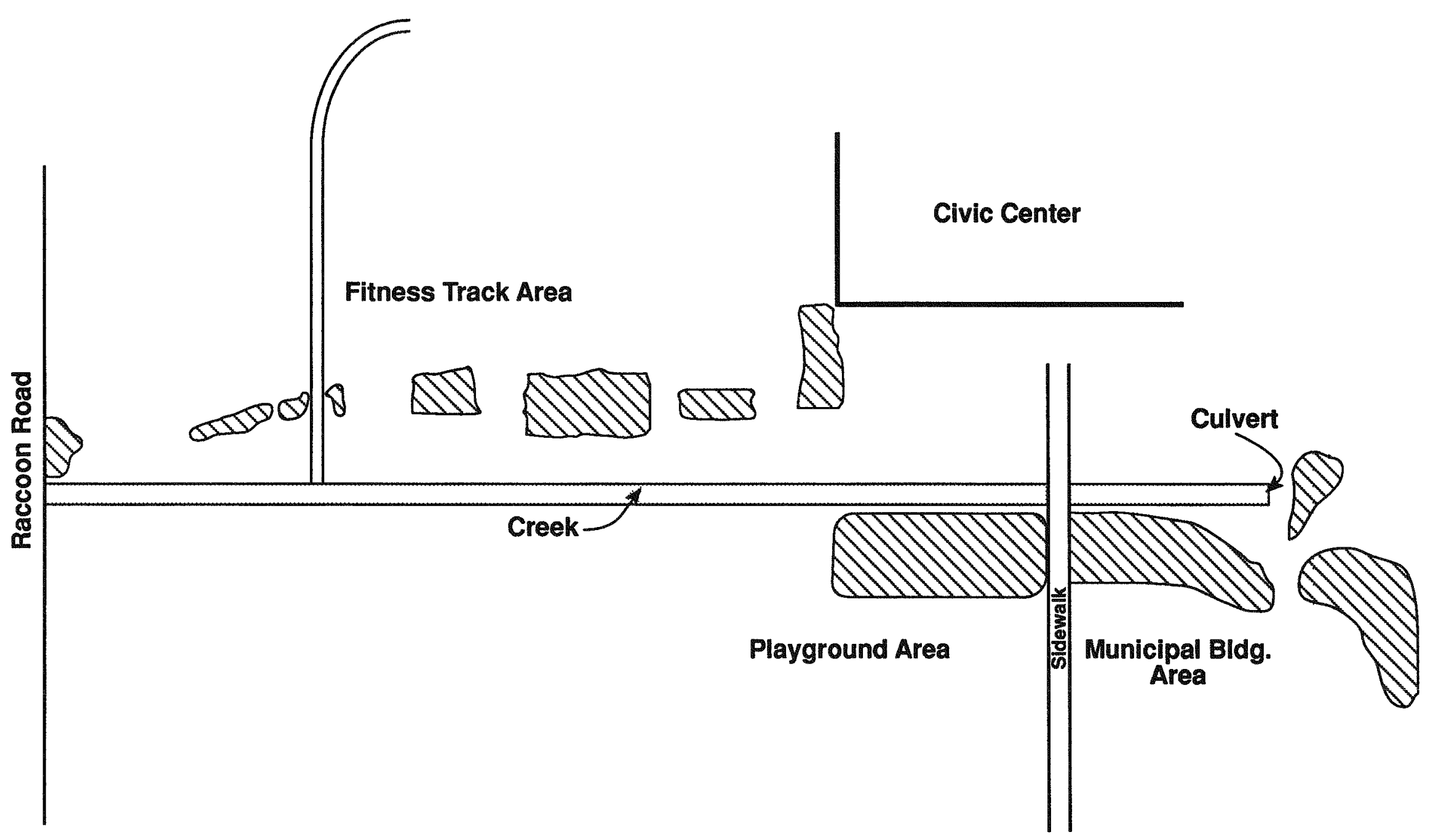

\section{MARTIN MARIETTA ENERGY SYSTEMS \\ ENVIRONMENTAL MGT. DEPT.}

Fig. 2.1. Remediated areas of the Oak Ridge Civic Center. 


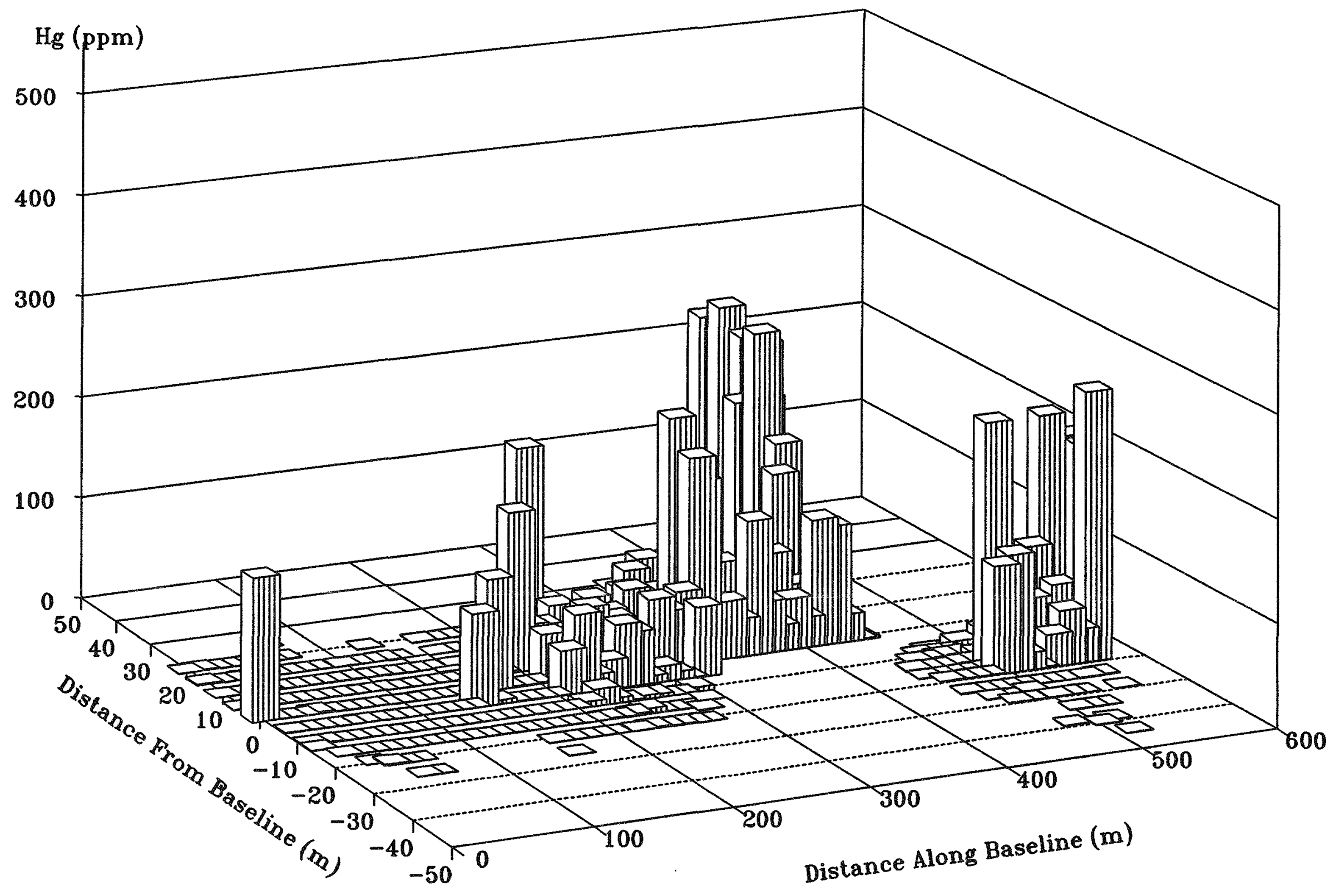

Fig. 2.2. Mercury concentrations at Civic Center fitness track and playground before remediation (ORAU 1983-4 Survey Database). 


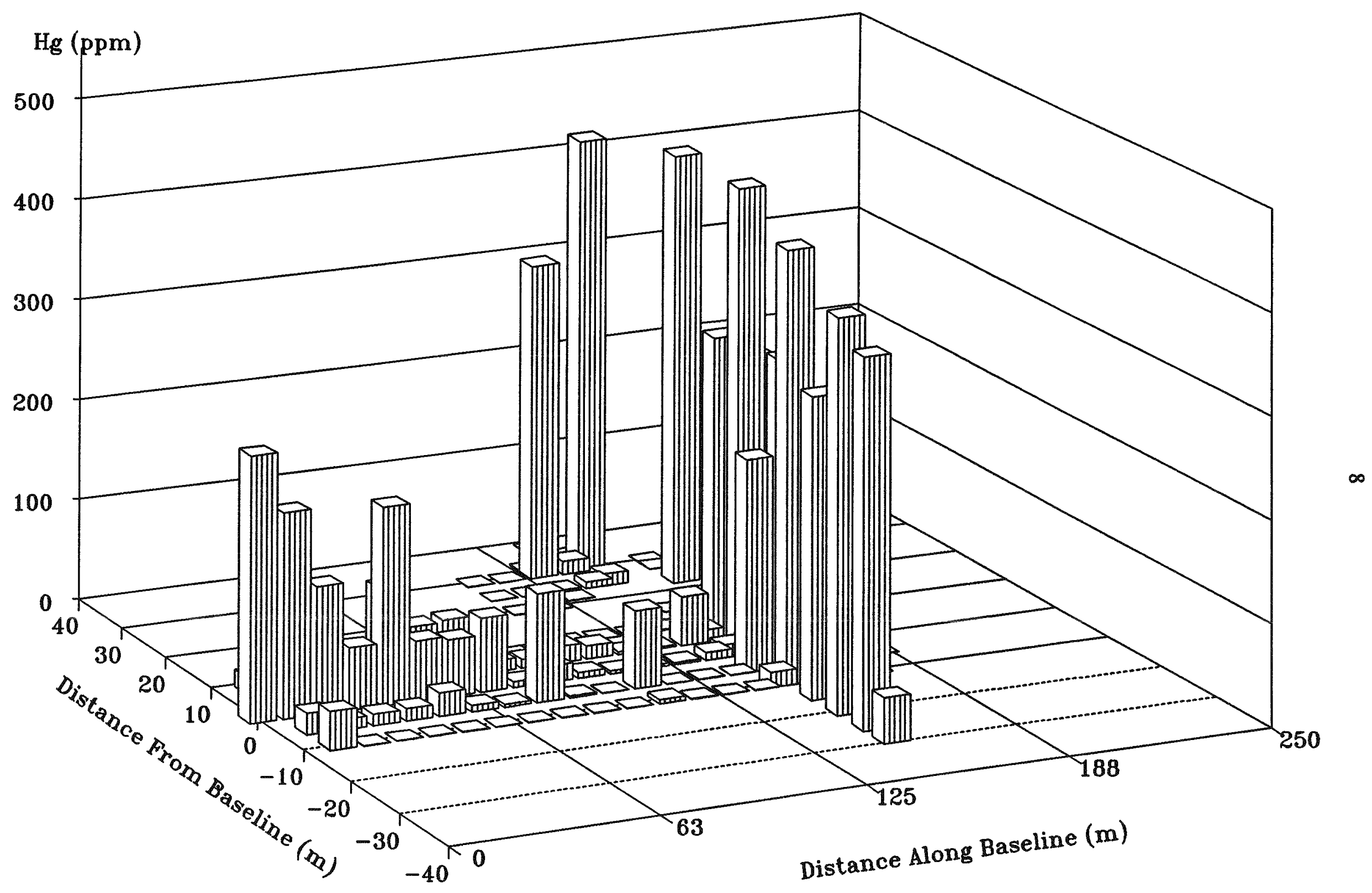

Fig. 2.3. Mercury concentrations near Oak Ridge Municipal Building Building before remediation (ORAU 1983-4 Survey Database). 


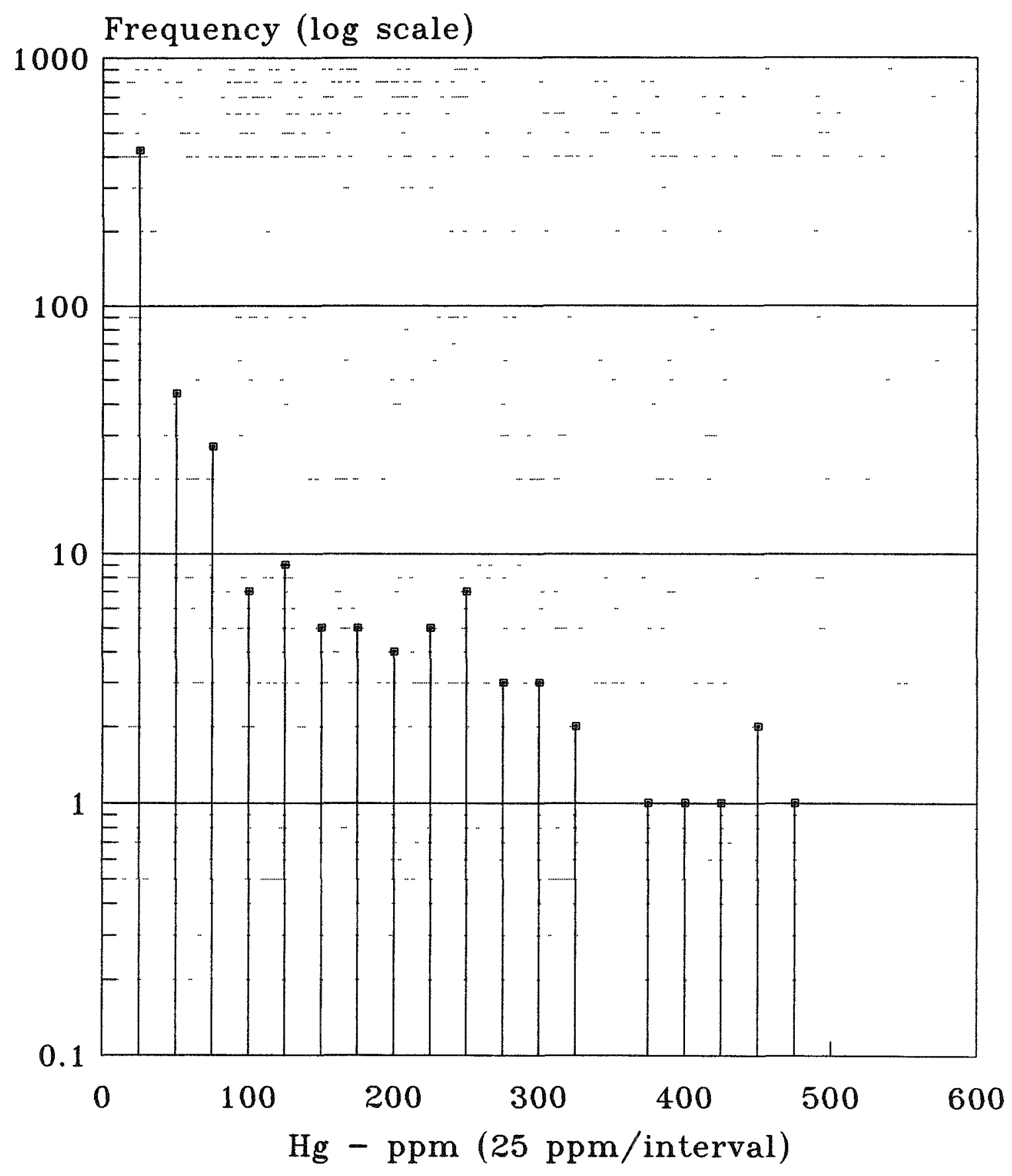

Fig. 2.4. Distribution of mercury concentrations in areas prior to remediation at Oak Ridge Civic Center. 
analyses of the TCLP extract were all reported less than the laboratory detection limit (CompuChem Laboratories, 1991). These results are supported by sequential extraction studies performed by Revis (1989) where EFPC soils were found to contain mercuric sulfide that would not leach with nitric acid. The nonvalidated results are as follows:

$\begin{array}{lcc}\text { Compound } & \text { TCLP Leachate(mg/L) } & \text { Total Analysis(mg/kg) } \\ \text { Arsenic } & <2.5 & 17.6 \\ \text { Barium } & <50 & 740 \\ \text { Cadium } & <0.5 & 46.1 \\ \text { Chromium } & <2.5 & 73.6 \\ \text { Lead } & <2.5 & 113 \\ \text { Selenium } & <0.5 & 1.4 \\ \text { Silver } & <0.5 & 26 \\ \text { Mercury } & <0.1 & 2240\end{array}$

\subsubsection{Data Quality, Objectives, and Uses}

Data of two different quality levels will be generated during the field sampling of the CRBAWP. Data quality Levels I and IV, as defined in Data Quality Objectives for Remedial Response Activities (USEPA, 1987) will be provided. Level I data will be obtained primarily through health and safety monitoring by the collection of data on mercury vapors, organic vapors, and radiation levels. It may or may not be used in evaluating the results of the laboratory tests, but it does provide real-time data for health and safety considerations and an indication of the presence or absence of contamination. Analytical laboratory data generated from the analysis of soil samples will meet the requirements for Level IV data quality. Level IV data is characterized by rigorous QA/QC protocols and documentation. The type and amount of documentation for laboratory analysis will be determined by the requirements of each analytical procedure. Documentation for both analytical and field procedures is discussed in the RCRA Facility Investigation (RFI) QAPP (Wiggins, 1988a) and the Environmental Surveillance Procedures, Quality Control Program (Energy Systems, 1988).

The following are the data objectives for the CRBAWP work plan:

1. To obtain representative samples from the waste pile for TCLP analyses,

2. To determine TCLP-extract contaminant levels for waste pile characterization,

3. To determine levels of uranium and polychlorinated biphenyls (PCBs) in soils,

4. To ensure a minimum of extraneous or cross-contamination of samples, and

5. To provide data with of a high degree of confidence.

\subsubsection{Analytical Methods and Detection Limits}

Based on results from previous sampling of the EFPC soils, the parameters selected for soil analyses include the full TCLP list as well as PCBs and uranium. Table 2.1 lists the extraction and analytical methods and the required detection limits for each. 
Table 2.1. Analytical methods and detection limits

\begin{tabular}{|c|c|c|}
\hline Compound & $\underline{\text { Method }^{1}}$ & $\frac{\text { Detection }}{\underline{\text { Limits }}}$ \\
\hline Arsenic & 6010 & $53 \mu \mathrm{g} / \mathrm{L}$ \\
\hline Barium & 6010 & $2 \mu \mathrm{g} / \mathrm{L}$ \\
\hline Benzene & 8020 & $0.2 \mu \mathrm{g} / \mathrm{L}$ \\
\hline Cadmium & 6010 & $4 \mu \mathrm{g} / \mathrm{L}$ \\
\hline Carbon Tetrachloride & 8010 & $0.12 \mu \mathrm{g} / \mathrm{L}$ \\
\hline Chlordane & 8080 & $0.014 \mu \mathrm{g} / \mathrm{L}$ \\
\hline Chlorobenzene & 8020 & $0.2 \mu \mathrm{g} / \mathrm{L}$ \\
\hline Chloroform & 8010 & $0.05 \mu \mathrm{g} / \mathrm{L}$ \\
\hline Chromium & 6010 & $7 \mu \mathrm{g} / \mathrm{L}$ \\
\hline O-Cresol & 8040 & $\mathrm{NA}^{3}$ \\
\hline M-Cresol & 8040 & NA \\
\hline P-Cresol & 8040 & NA \\
\hline Cresol & 8040 & NA \\
\hline $2,4-D$ & 8040 & $0.39 \mu \mathrm{g} / \mathrm{L}$ \\
\hline 1,4-Dichlorobenzene & 8010 & $0.24 \mu \mathrm{g} / \mathrm{L}$ \\
\hline 1,2 - Dichloroethane & 8010 & $0.07 \mu \mathrm{g} / \mathrm{L}$ \\
\hline 1,1 - Dichloroethylene & 8010 & $0.13 \mu \mathrm{g} / \mathrm{L}$ \\
\hline 2,4-Dinitrotoluene & 8090 & $0.02 \mu \mathrm{g} / \mathrm{L}$ \\
\hline Endrin & 8080 & $0.006 \mu \mathrm{g} / \mathrm{L}$ \\
\hline Heptachlor & 8080 & $0.003 \mu \mathrm{g} / \mathrm{L}$ \\
\hline Hexachlorobenzene & 8120 & $0.05 \mu \mathrm{g} / \mathrm{L}$ \\
\hline Hexachlorobutadiene & 8120 & $0.34 \mu \mathrm{g} / \mathrm{L}$ \\
\hline Hexachloroethane & 8010 & NA \\
\hline Lead & 6010 & $42 \mu \mathrm{g} / \mathrm{L}$ \\
\hline Lindane & 8080 & NA \\
\hline
\end{tabular}


Table 2.1. (continued)

\begin{tabular}{|l|c|c|}
\hline \multicolumn{1}{|c|}{ Compound } & Method & Detection \\
& & $\underline{\text { Limits }}$ \\
\hline Mercury & 7470 & $0.0002 \mathrm{mg} / \mathrm{L}$ \\
\hline Methoxychlor & 8080 & $0.176 \mu \mathrm{g} / \mathrm{L}$ \\
\hline Methyl Ethyl Ketone & 8015 & $\mathrm{NA}$ \\
\hline Nitrobenzene & 8090 & $13.7 \mu \mathrm{g} / \mathrm{L}$ \\
\hline Pentachlorophenol & 8040 & $7.4 \mu \mathrm{g} / \mathrm{L}$ \\
\hline Pyridine & 8090 & $\mathrm{NA}$ \\
\hline Selenium & 6010 & $75 \mu \mathrm{g} / \mathrm{L}$ \\
\hline Silver & 6010 & $7 \mu \mathrm{g} / \mathrm{L}$ \\
\hline Tetrachloroethylene & 8010 & $0.03 \mu \mathrm{g} / \mathrm{L}$ \\
\hline Toxaphene & 8080 & $0.24 \mu \mathrm{g} / \mathrm{L}$ \\
\hline Trichloroethylene & 8010 & $0.12 \mu \mathrm{g} / \mathrm{L}$ \\
\hline $2,4,5$ - Trichlorophenol & 8040 & $\mathrm{NA}$ \\
\hline $2,4,6$ - Trichlorophenol & 8040 & $0.64 \mu \mathrm{g} / \mathrm{L}$ \\
\hline $2,4,5$ - TP (Silvex) & 8150 & $0.17 \mu \mathrm{g} / \mathrm{L}$ \\
\hline Vinyl Chloride & 8010 & $0.18 \mu \mathrm{g} / \mathrm{L}$ \\
\hline PCBs (1242) & 8080 & $0.065 \mu \mathrm{g} / \mathrm{L}$ \\
\hline Total Uranium & EC $1950^{2}$ & $0.001 \mathrm{mg} / \mathrm{L}$ \\
\hline $235 \mathrm{E}$ & $\mathrm{EC} 1950^{2}$ & $0.001 \mathrm{mg} / \mathrm{L}$ \\
\hline
\end{tabular}

${ }^{1}$ U.S. EPA Test Methods for Evaluating Solid Waste, Third Edition, SW-846, November 1986

${ }^{2}$ EC 1950 - Isotope Dilution Mass Spectrometric Method - Martin Marietta Multi-Plant Procedure

3 NA - Detection Limit not stated 


\subsubsection{Statistical Evaluation}

After verification and validation of the laboratory results, a series of statistical analyses will be performed. All analyte values that were below the detection limit will be set to onehalf of the detection limit. The first analysis will be a determination of whether or not the data is normally distributed. If the data is not normally distributed (the most likely case), a $\log$ transformation will be accomplished. All subsequent analyses will be done using logtransformed data. For each analyte of concern, the mean, standard deviation, standard error, and the $95 \%$ confidence intervals will be calculated. The data collected from this study will be loaded into a Statistical Analysis System (SAS). All subsequent calculations will be carried out using the SAS programming language. The confidence interval will then be compared against the regulatory levels outlined in 40 CFR 261, Appendix II, and applicable or relevant and appropriate requirements.

If, after transformation, the data is not normally distributed, additional transformations will be conducted. If this fails, a non-parametric test will be used to evaluate the data.

\subsection{MEDIA}

\subsubsection{Soils}

Soil contained within the CRBAWP is the only media of concern for this sampling plan. Because EFPC floodplain soils were used as a topsoil cover in the Oak Ridge Civic Center area and along the Sewer Line Beltway, a characterization of the leachability of contaminants from this soil is necessary. The contaminants investigated will be in accordance with the full TCLP list and knowledge of other contaminants within the EFPC floodplain, notably uranium and PCB.

\subsubsection{Groundwater}

Because it is constructed with plastic liners above and below, groundwater at the CRBAWP site is not a media to be considered within the scope of this work plan. While it may be addressed in the closure plan for the waste pile, characterization of the groundwater is not necessary to determine if the waste pile should be closed as a hazardous or nonhazardous facility.

\subsubsection{Surface Water}

No surface water is present in the vicinity of the CRBAWP; therefore, no characterization is required. 


\subsubsection{Ambient Air}

While ambient air monitoring will be required for health and safety considerations during intrusive sampling activities, ambient air quality is not affected by the soils within the CRBAWP. No air sampling is proposed in this work plan.

\subsection{FIELD SAMPLING PLAN}

\subsubsection{Soil Sampling Procedures}

Sampling will be conducted in accordance with Energy Systems Environmental Surveillance Procedures (ESP)-300 series on soil sampling. Two primary methods of sampling will be employed for differing thicknesses of the pile. Of prime importance with either type of sampling is that the underlying plastic liner not be penetrated.

In the shallow areas $(<4 \mathrm{ft}$ ) of the waste pile (see Figure 1.2), samples to a depth of 1 $\mathrm{ft}$ will be obtained using a spade and scoop per ESP 303-1. The sample will be placed directly into the sample container after being scooped from the pile. This is done to ensure that volatile compounds are not released. Before taking the sample, a plastic sheet will be spread around the work area to provide a clean surface. Any sample preparation will take place on the plastic cover and all equipment not in use will be placed on the cover.

In the deeper areas of the waste pile, a small, portable drill rig will be used to take samples at depth using a split-spoon sampler per ESP-303-4. A 3-ft split spoon sample will be taken at all locations except where shallow sampling is designated (see Sect. 2.4.2, Soil Sampling Locations). In selected areas where the waste pile is 10 - to 12 -ft thick (center of the pile - see Figure 1.2), three successive spoons will be taken to a depth of $9 \mathrm{ft}$. After recovery, the spoon will be opened and monitored for health and safety parameters. Two samples will then be taken. One sample for volatile compounds will be removed directly from the split-spoon into the sample container. The team member should attempt to obtain equal portions over the 3-ft length to fill the jar. For the second sample, the contents will be scooped out into a large stainless steel bowl and homogenized before filling the sample container. Excess soil will be retained until the last spoon is recovered and then placed back into the hole. The abandoned hole will be back-filled with adjacent soils to eliminate potential problems with an open hole.

\subsubsection{Sample Volumes and Container}

Sample volumes will be enough to fill a $32-0 z$ glass jar and a $50-\mathrm{mL}$ plastic centrifuge cone (uranium analysis). For samples from split-spoons, two $32-0 z$ glass jars with teflon lined lids will be required: one jar will be for volatile compounds from the TCLP list, while the other will be utilized for the remaining analyses. Sample containers can be obtained from the Environmental and Radiochemistry Laboratory at Building 9769. Sample labels and tags will be placed on each container, displaying, at a minimum, the sample number, location sample media, sample type, analysis, rad screening, sample date/time, and collector's initials. 


\subsubsection{Soil Sampling Locations}

The waste pile was divided into a 10 -ft grid pattern consisting of 140 individual cells (Figure 2.5). Originally, 15\% of the cells $(21 / 140)$ were randomly selected for sampling; however, those lying at the edge of the pile were omitted and some deep samples located at the boundary between thin and thick portions of the pile were altered to ensure protection of the underlying liner. Additional samples were added to the deeper intervals in the thickest portion of the waste pile. The final count is nine samples at 0 to $1 \mathrm{ft}$ and nine samples at 0 to $3 \mathrm{ft}$, four samples at 3 to $6 \mathrm{ft}$, and four samples at 6 to $9 \mathrm{ft}$ for a total of 26 samples. With the 26 samples to be taken, 18 cells out of the 140 cells within the waste pile outline will be represented for $13 \%$ of the total. Table 2.2 lists sample numbers, locations, and depths.

\subsubsection{Sample Preservation, Packaging, and Shipment}

Preservation of soil samples will consist of cooling the samples to a maximum of $4^{\circ} \mathrm{C}$. No additional preservatives are required. ESP-701, Sample Preservation and Container Materials, will be followed if any questions arise. Samples will be packed for delivery in accordance with ESP-800, Packaging Environmental Samples for Transportation, although the samples can be hand-carried to the Y-12 Plant Environmental and Radiochemistry Laboratory at Building 9769. An environmental requisition form (Appendix A), which specifies the analyses to be performed, must accompany the samples. The form will contain the unique sample ID number and a determination code for the particular analysis. The following codes will be required for this work:

$\begin{array}{ll}\text { Total Uranium } & -139 \\ { }^{235} \mathrm{U} & -142 \\ \text { PCBs } & -221 \\ \text { TCLP } & -346\end{array}$

Completion of analyses within holding times will be crucial to the success of this work plan. The critical path is for TCLP purgeable organics, which have a maximum holding time of 14 days from collection to TCLP extraction and another 14 days from leachate extraction to analysis. Mercury, the primary contaminant, has a requirement of 28 days from collection to TCLP extraction and another 28 days for analysis. Scheduling with the Y-12 Plant Environmental and Radiochemistry Laboratory (office telephone 574-2904) for laboratory services before sampling will ensure that holding times are met.

\subsubsection{Field QA/QC Samples}

In addition to the 26 samples to be taken for TCLP analyses, a series of field QC samples will be submitted to provide a high level of QA for the results. At a minimum rate of 1 in 20 , one colocated sample or duplicate will be taken and submitted to determine variability between samples. At least one field-prepared blank consisting of organic-free high 


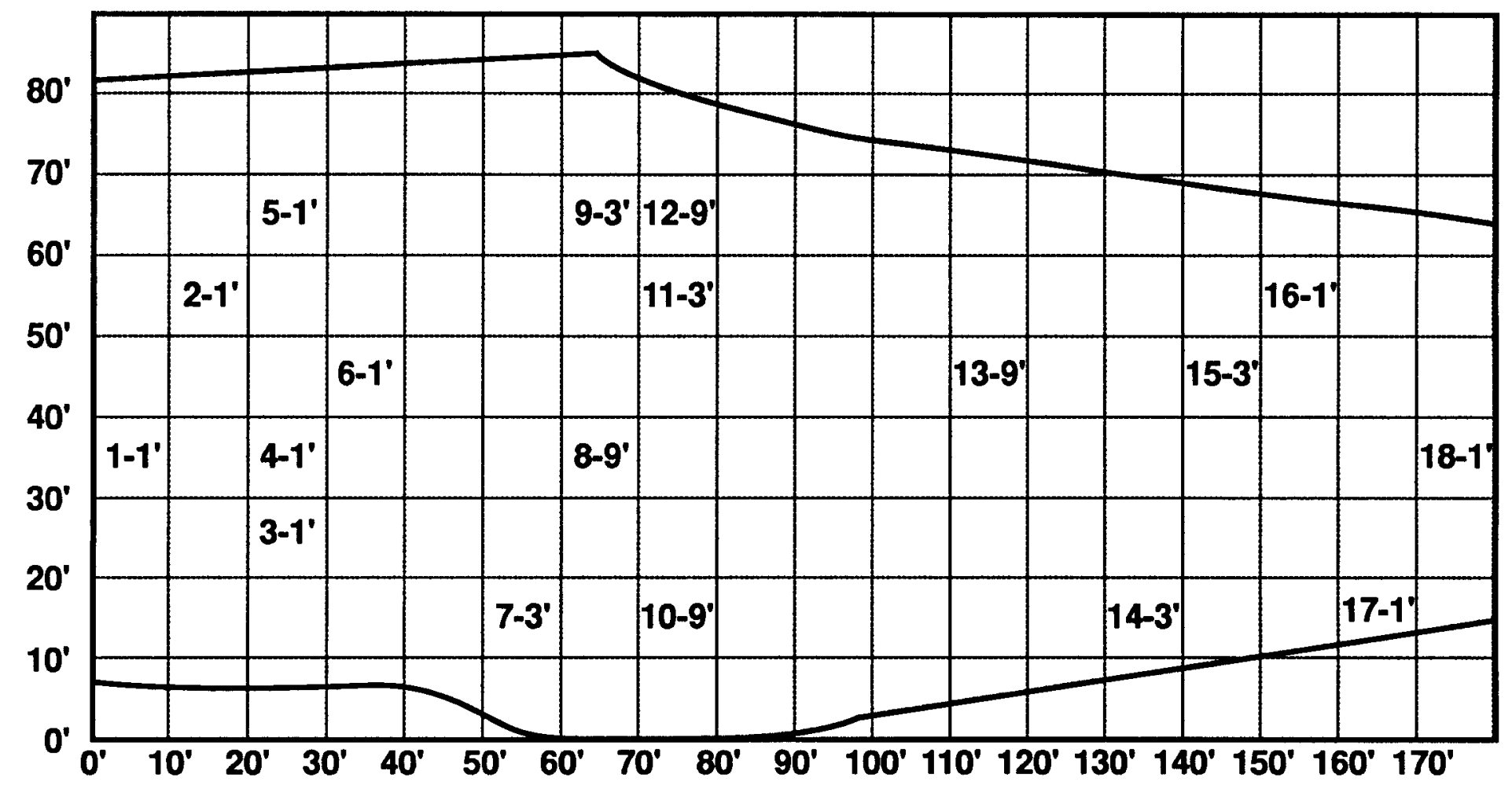

$\bar{a}$

\section{LEGEND}

10-9' $=$ Location Number -10

Lowest Depth Sampled - 9
MARTIN MARIETTA ENERGY SYSTEMS ENVIRONMENTAL MGT. DEPT.

Fig. 2.5. Sampling design for CRBAWP. 
Table 2.2. Sample apportionment

\begin{tabular}{|c|c|c|c|c|c|}
\hline Location \# & Sample \# & Depth (ft) & \multicolumn{2}{|c|}{$\begin{array}{l}\text { Coordinates } \\
x(\mathrm{ft}) \quad y(\mathrm{ft})\end{array}$} & Method \\
\hline 1 & 1 & $0-1$ & 5 & 35 & scoop \\
\hline 2 & 2 & $0-1$ & 15 & 55 & scoop \\
\hline 3 & 3 & $0-1$ & 35 & 25 & scoop \\
\hline 4 & 4 & $0-1$ & 35 & 35 & scoop \\
\hline 5 & 5 & $0-1$ & 35 & 65 & scoop \\
\hline 6 & 6 & $0-1$ & 45 & 45 & scoop \\
\hline 7 & 7 & $0-3$ & 65 & 15 & split spoon \\
\hline \multirow[t]{3}{*}{8} & 8 & $0-3$ & 75 & 35 & split spoon \\
\hline & 9 & $3-6$ & 75 & 35 & split spoon \\
\hline & 10 & $6-9$ & 75 & 35 & split spoon \\
\hline 9 & 11 & $0-3$ & 75 & 65 & split spoon \\
\hline \multirow[t]{3}{*}{10} & 12 & $0-3$ & 85 & 15 & split spoon \\
\hline & 13 & $3-6$ & 85 & 15 & split spoon \\
\hline & 14 & $6-9$ & 85 & 15 & split spoon \\
\hline 11 & 15 & $0-3$ & 85 & 55 & split spoon \\
\hline \multirow[t]{3}{*}{12} & 16 & $0-3$ & 85 & 65 & split spoon \\
\hline & 17 & $3-6$ & 85 & 65 & split spoon \\
\hline & 18 & $6-9$ & 85 & 65 & split spoon \\
\hline \multirow[t]{3}{*}{13} & 19 & $0-3$ & 115 & 45 & split spoon \\
\hline & 20 & $3-6$ & 115 & 45 & split spoon \\
\hline & 21 & $6-9$ & 115 & 45 & split spoon \\
\hline 14 & 22 & $0-3$ & 135 & 15 & split spoon \\
\hline 15 & 23 & $0-3$ & 145 & 45 & split spoon \\
\hline 16 & 24 & $0-1$ & 155 & 55 & scoop \\
\hline 17 & 25 & $0-1$ & 165 & 15 & scoop \\
\hline 18 & 26 & $0-1$ & 175 & 35 & scoop \\
\hline
\end{tabular}


purity water will be submitted. One trip blank (for each day that sampling occurs) will also be prepared at the staging area with organic-free high purity water, then carried to the field and shipped to the laboratory for analysis.

One equipment rinsate will be prepared for each day's activities. The individual piece of equipment from which the rinsate was taken will be noted or a composite rinsate from all the equipment used will be submitted.

\subsubsection{Equipment Decontamination Procedures}

To ensure against cross-contamination, all sample containers, sampling devices, and equipment must be cleaned and decontaminated before the first use and between each sample, according to methods described in ESP-900 Cleaning and Decontaminating Sample Containers and Devices and ESP-901 Equipment Decontamination. The cleaning solvent will be pesticide-grade isopropanol and organic-free water as a final rinse. Liquids will be containerized and held on-site pending analyses of a liquid sample analyzed for the same parameters as the soil. In addition, the rig must be decontaminated after completion of the sampling project and before removal from the site.

\subsection{SAMPLE DOCUMENTATION/HANDLING}

\subsubsection{Sample Identification Numbers}

Sample numbers are listed in Table 2.2 and are ordered sequentially across the waste pile. A project code identifier should also be included in the sample ID. The project manager, at his/her discretion, may renumber the above list to make it more suitable for the logistics of the sampling program.

\subsubsection{Site Logbook}

The site logbook is the master field investigation document. It is a bound book with hard cover and sequentially numbered pages. The primary purpose of this logbook is to document each day's field activities, the personnel on each sampling team, and any administrative occurrences, conditions, or activities that may have affected the field work or data quality of any environmental samples for any given day. The site logbook will be kept by the team leader. The front of the logbook will be used to list the site name, the names of the companies performing the field sampling, and the names of the subcontractors (such as the drilling company's and driller's names). The site logbook will be updated daily. Following his/her review, the team leader will sign the bottom of each page. The site logbook will, at a minimum, contain the following information: (1) day, date, arrival time on-site, temperature, weather conditions, and names and titles of personnel present on-site; (2) names, titles, and organizations of any visitors who entered the site during the day; (3) chainof-custody details, sample forms, sample label/tag numbers, types of samples, and laboratories to which samples were sent; (4) arrival time of subcontractors on-site, number of feet drilled, 
total recovery of soil samples, number of duplicate samples, number of QC samples; (5) number of samples and any field tests; (6) decontamination iterations, equipment decontaminated, and procedures used; (7) specific comments relative to any problem areas that occurred during the day, the final resolution, and the anticipated impact on the outcome of the field investigation on data quality; and (8) instruments calibrated during the day, the individual who performed the calibration, and the reference to the page number in the calibration $\log$ that provides more specific information on calibration procedures and results.

\subsubsection{Chain of Custody}

Chain-of-custody procedures will be as detailed in ESP-500. The person delivering or shipping the samples from the field to the laboratory is responsible for completing the chainof-custody form, including referencing all QC samples, signing the form, and noting the date and time of delivery. The team leader will also inspect the form for completeness and accuracy. Any corrections to the chain-of-custody form entries will be initialed by the person who made the change. Upon delivery, the form will be signed by a representative of the Environmental and Radiochemistry Laboratory and custody will become the responsibility of the laboratory. A copy of the chain-of-custody form will be retained by the team member and filed appropriately for future use. 


\section{WASTE MANAGEMENT PLAN}

\subsection{PURPOSE AND SCOPE}

The purpose of this section is to identify the responsibilities and activities necessary to provide for the proper and safe handling of waste generated by the CRBAWP sampling activities. However, waste generated during the CRBAWP sampling will be managed as nonhazardous waste until analytical results indicate otherwise. Also, this plan is intended to supplement the objectives established in the decontamination procedures.

\subsection{ROLES AND RESPONSIBILITIES}

\subsubsection{Energy Systems (Y-12 Plant Waste Management Division)}

The roles and responsibilities of the Energy Systems Y-12 Plant Waste Management Division include: (1) if the waste is determined to be hazardous by TCLP analysis, accept waste into interim 90-day storage facility; (2) implement the appropriate waste handling and/or storage activities in accordance with federal and state regulations and the policies and procedures of Energy Systems, as determined by the waste characterization; (3) make the final determination for disposition of all waste generated during the CRBAWP sampling.

\subsubsection{CRBAWP Project Manager}

Once the waste is determined to be hazardous, the CRBAWP project manager's roles and responsibilities are: (1) coordinate with the Y-12 Plant Waste Management Division for the 90-day interim storage of waste containers; (2) coordinate with the Y-12 Waste Management Division and the team leader for the proper transfer of waste containers; (3) ensure that the sampling team members are familiar with and understand the requirements defined in the accompanying health and safety plan.

\subsubsection{CRBAWPSampling Team Leader}

The CRBAWP sampling team leader's roles and responsibilities include: (1) ensure the required waste containers are available for each sampling effort; (2) ensure the required waste containers are labeled and marked correctly; (3) coordinate with the Y-12 Plant Waste Management Division for the pickup and transport of waste containers; (4) ensure that the sampling team members follow the requirements defined in the health and safety plan.

\subsubsection{CRBAWPSampling Team Members}

The CRBAWP sampling team members' roles and responsibilities include: (1) minimize the generation of waste and segregate the waste generated (clean from contaminated) by 
placing the waste materials in the appropriately marked containers; and (2) adhere to the requirements defined in the health and safety plan.

\subsection{WASTE GENERATION}

\subsubsection{Waste Types}

Five general categories of waste must be considered:

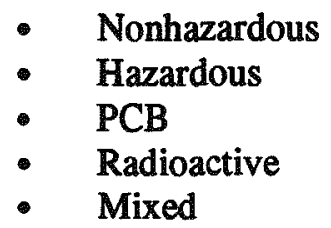

Waste generated by the CRBAWP sampling activities will be stored on-site until results are available. Due to its location within the Y-12 Plant boundary, the CRBAWP is restricted from public access. Furthermore, all waste generated during the activities will be immediately containerized.

The CRBAWP sampling activities will generate the following types of wastes:

1. Decontamination Fluids: This waste is generated by the cleaning of sampling equipment performed between taking samples and the final cleanup at the end of the day's sampling activities. Residual soils and sediments with contaminants may become suspended in the decontamination fluid during cleaning. Cleaning fluids, such as laboratory detergents, pesticide-grade isopropanol, organic free water, tap water, and deionized water, may be used. These fluids will be stored on site in 55-gal drums until a determination is made.

2. Incidental Waste: This waste includes disposable personal protective equipment (PPE), used plastic liners, wipes, aluminum foil, and duct tape. This waste should be collected in a solid waste 55-gal drum and also stored on site.

3. Miscellaneous Waste: This waste includes only clean waste which did not come in contact with sample media. This waste is considered to be sanitary waste and may be disposed of as such. Examples include: plastic/foam packing, food wastes, paper, backs removed from labels and/or stickers, and leftover materials from chain-ofcustody packages. This waste should be collected in a heavy-duty plastic garbage bag.

Any excess soil not placed in sample containers or soil inadvertently dropped or otherwise unusable will be returned to the sample hole from which it was obtained. 


\subsubsection{Waste Volumes}

The sampling team should minimize the generation of waste and segregate the waste generated (clean from contaminated) by placing the waste materials in the appropriately marked containers. The types of waste to be generated and the estimated volume of these wastes are described below. The volume estimates are based on field experience and will vary depending on the amount of cleaning/rinsing required to adequately wash and rinse the sampling equipment.

Decontamination Fluids: The fluids produced by decontamination of the sampling equipment and sample containers will be collected in 55-gal liquid waste drums during the change-out of rinse or wash fluids or at the end of the day's sampling activities. The decontamination for a standard sample includes a soap/detergent wash, tap water rinse, deionized water rinse, and an acid/solvent (isopropanol) rinse. The waste generation for this level of decontamination is estimated to be 4 to $6 \mathrm{ft}^{3}$ (30 to $44 \mathrm{gal}$ ) per 10 samples; therefore, approximately three 55 -gal drums will be required.

Incidental Waste: The incidental solid waste generated by the CRBAWP sampling activities will be collected in a solid waste 55-gal drum. The estimate for volume of incidental waste is 3 to $5 \mathrm{ft}^{3}$ per 20 samples.

Miscellaneous Waste:The miscellaneous waste generated by the CRBAWP sampling activities will be collected in a large, extra-strength garbage bag. The volume of miscellaneous waste to be generated is estimated to be 1 to $3 \mathrm{ft}^{3}$ per 20 samples.

Laboratory Waste: The analytical laboratory is responsible for the proper disposal of all sample materials and residuals.

\subsection{WASTE HANDLING AND DISPOSITION}

\subsubsection{Waste Segregation}

Potentially-contaminated materials will be segregated from waste materials expected to be clean. Contamination control efforts will be implemented at each sampling and decontamination location to minimize waste generation.

\subsubsection{Container Identification/Labeling}

The decontamination fluids will be stored on-site until laboratory analysis is received. The drum should be labeled "Decontamination Fluids-CRBAWP Sampling" with the date of generation. The incidental waste should be marked "Incidental Waste-CRBAWP Sampling" with the date of generation. The miscellaneous waste can be disposed of as sanitary waste. 
A sequential drum number with a sample location identifier will be assigned to each drum upon receipt at the field sampling location and recorded in the site logbook.

\subsubsection{Container Storage}

The filled drums will be maintained on-site at the CRBAWP until a determination is made of whether the waste is hazardous or nonhazardous. A liquid sample will be obtained and submitted for analysis of the same parameters as the soils. Upon determination of a hazardous status, the generator has 72 hours to transfer the waste to a permitted 90-day area. Within that 72 hours, the drums will be transported to a location designated by the $Y-12$ Plant Waste Management Division. Additional requirements for labeling and marking will be included as identified by the Waste Management Division. The transfer of drums should be recorded in the site logbook to include: date of transfer, drum identifier, and label. 


\section{DATA MANAGEMENT}

\subsection{DATA STRUCTURE AND TYPE}

A common sample coding and data structure format has been developed for the storage and retrieval of the field sampling and laboratory analysis data. The sample coding format used will be compatible with Energy Systems-Oak Ridge Environmental Information System (in preparation) for environmental restoration data.

The field data collected by the field team will include field sample information, details on field conditions, field instrument measurements, and any deviations from prescribed plans or procedures. The team leader will send to the data management coordinator (DMC) all required data packages (consisting of copies of field results, field logbooks, and field notes) on a daily basis.

The data received from the analytical laboratory will include the results from routine field samples, field QA/QC samples, laboratory QA/QC samples, and any data flags placed on the results by the laboratory analysts to explain any deviations from prescribed procedures or methods.

\subsection{DATA FLOW}

\subsubsection{Field Sampling Data}

The field sampling data to be included in the CDB will consist of: (1) details on field conditions, (2) field instrument measurements, and (3) task team activity logs including chainof-custody information, deviations from plan, QA concerns, and any noteworthy observations. The data collected by the field sampling team will be entered into a personal computer (PC) by a data entry operator using the verified field forms for data entry. All data will be entered twice and the resulting files will be compared. Changes will be iterated until the final correct file is produced. The actual field measurements, field observations, deviations from the sampling plan, and task team activity logs will be included in the data bases. All field information will then be transferred from the PC to an SAS data base on a VAX computer. Paper copies of all field data will be indexed, cataloged, and placed in the project file.

\subsubsection{Laboratory Data}

The analytical laboratory data collected for this study will include: (1) sample management and tracking data, (2) sample custody documentation, (3) analytical results from the field samples, and (4) analytical results from the field QA/QC samples (duplicates, trip, equipment, and field blanks). Data from the analytical laboratories will be transferred electronically from a PC floppy disk prepared by the analytical laboratory to an SAS data base 
on a VAX computer. The analytical laboratory will have the responsibility for verification of the electronic data prior to release. Paper copies of all analytical data including QA forms will be indexed, cataloged, and placed in the project file.

\subsubsection{Raw Data Base}

The data received from the field activities and the analytical laboratory will initially be stored in an invalidated data base. After passing through validation procedures, the data will be updated and stored in the validated data base. All subsequent summaries, statistical analyses, and reports will be generated from the data contained in the validated data base.

After storing the data in the appropriate consolidated data base files, the DMC will perform an internal data consistency check. This check will involve the use of data validation programs designed for sorting the data and comparing the data identifiers to one another to determine if any information is missing, mislabeled, or duplicated due to data transcription or data transmittal errors.

Manual data checks will then be performed to verify data entry accuracy, compare data values to field notes, and compare questionable data values to data previously collected at or near the same sampling or measurement location. Data flags that qualify data values will be set as required. The accuracy and precision of the data will be determined by evaluating the trip blanks, field blanks, equipment blanks, and replicate field and laboratory samples.

All data determined to be incorrect using the previously described procedures will be reconciled. The DMC will perform all data reconciliation activities with accompanying error correction logs, document control, and data base update methods. Any changes to the data base from its receipt from the analytical laboratory or the field to its final form will be documented. All verified data inconsistencies will be corrected by recording information into an error correction log and updating the data base with the correct value. A log of program changes will be kept in an SAS program audit file. All changes will be commented in the program audit file stating why changes were made. This log will specify the sample identification number, the field to be corrected, the incorrect value, the correct value, the reason for the change, and the last name of the responsible person.

After passing through the verification and validation procedures, the data will be updated and stored in a "validated" data base. All subsequent summaries, analyses, and reports will be generated from the data contained in the validated data base. 


\section{HEALTH AND SAFETY PLAN}

\subsection{INTRODUCTION}

The CRBAWP contains approximately $3000 \mathrm{yd}^{3}$ of mercury contaminated soil originally obtained from the EFPC floodplain. Its investigation will utilize best management practices to provide for worker safety since the site has not been shown to involve hazardous waste operations. Most of these practices were derived from past experiences with the EFPC RI which perform many of the same activities considered for the CRBAWP. No analytical data, personal or onsite health and safety monitoring to date has indicated conditions which create concern for acute exposure. Nonetheless, a check list is supplied in Appendix B which covers the range of potential problems. Since the work at CRBAWP has not been scheduled and the sampling team members have not been identified, sections of the check list must be completed at the appropriate time.

A site health and safety officer (SHSO) shall be appointed by Energy Systems or by the subcontractor to ensure that the site safety and health plan shall remain in compliance with 29 CFR 1910 as amended by 29 CFR 1910.120. The SHSO or an alternate shall implement, monitor, and assist the team leader in enforcing the Site Health and Safety plan. It is the duty of the SHSO to coordinate the plan and ensure its implementation. If a subcontractor is the SHSO, he/she may coordinate between Y-12 Plant Industrial Hygiene and Health Physics Departments on matters concerning employee health and safety, such as personal and on-site monitoring and incident reporting.

Occupational Safety and Health Administration (OSHA) 40-hour health and safety training as specified in 29 CFR 1910.120 shall be required for all employees engaged in hazardous waste operations regulated under the hazardous waste provision of CERCLA, as amended, and RCRA, as amended, as well as for employees involved in emergency response involving the handling and processing of hazardous substances. Personnel who have previously received the 40-hour training shall receive the required 8-hour annual refresher training. Managers and supervisors shall receive an additional 8 hours of instruction. All classroom training shall be supplemented with appropriate on-site orientation and instruction under an experienced and qualified individual.

Medical surveillance, as required by 29 CFR 1910.120, of all personnel involved in hazardous waste site operations shall be conducted. Baseline and annual physical examinations shall be performed by the Y-12 Plant Medical Center or a qualified occupational physician. Subcontractors shall be responsible for ensuring that their employees receive the required examinations. Persons who have not received the necessary physical examinations or who are not medically approved to perform their duties at a hazardous waste site shall be excluded from all areas of the site. 


\subsection{SITE HAZARD DESCRIPTION}

\subsubsection{Suspected Contamination}

The CRBAWP is a storage facility used to store mercury-contaminated soils. These materials came from the removal of soil from the Oak Ridge Civic Center, the Oak Ridge Sewer Line Beltway, and other areas within the city where mercury-contaminated soils from dredging were deposited. Mercury is the contaminant of concern for the sampling activity at the site; however, radionuclides and organic compounds may be present in low levels.

\subsubsection{Physical Hazards}

The primary hazards associated with the sampling activities at this site are the risks posed by the climatic conditions prevailing at the site during the sampling event. The SHSO shall implement and enforce all safety procedures associated with heat and/or cold stress. These procedures shall be followed explicitly to avoid accidents.

Although underground utilities should not be a problem at the CRBAWP, the location of underground utilities will be determined during the Y-12 Plant Excavation and Penetration Permit Procedure, EP-D-06. This procedure will be followed during all subsurface sampling operations. Workers will be required to wear the appropriate PPE, including approved eye protection, hard hats, and steel-toed boots. The use of the PPE will also protect workers from other natural hazards such as poisonous flora and fauna.

Access to the site shall be controlled to reduce the potential exposure of personnel to any contaminants that may be present and to prevent the dispersal of contaminants by personnel or equipment leaving the site. Site control efforts shall be the responsibility of the SHSO in coordination with the Y-12 Plant Industrial Safety and Safeguards and Security Departments.

\subsection{SITE HAZARD EVALUATION}

Because contamination requiring PPE above level D is not expected, the establishment of additional work area zones to control contamination should not be required. If, however, it becomes necessary to upgrade the protection level, three work area zones will be established (exclusion, contamination reduction, and support) in accordance with the methodology described in Welch (1987).

Unusual conditions at the site, such as the detection of peculiar odors, will be investigated by the SHSO. In cases of extremely high organic vapor readings ( $>50 \mathrm{ppm}$ ), the SHSO will stop work and contact the Y-12 Plant Industrial Hygiene Department to determine if any other immediate actions may be needed to mitigate health and safety concerns. 
In the unlikely event of radioactive contamination, whole-body counts of the affected site workers will be performed by the Y-12 Plant medical staff. Work at the landfill shall be suspended until the conditions abate or PPE shall be upgraded. Upon the continuance of operations, a personal dosimetry program shall be instituted by the Y-12 Plant Health Physics Department.

\subsection{PPE}

\subsubsection{Level Determination}

The level of personal protection required for sampling activities at the CRBAWP will be dictated by the location and type of sampling to be conducted. The planned activities consist of surface and subsurface sampling of the contaminated soil in the waste pile. The personnel protection level recommended is Level $\mathrm{D}$, which is defined in 29 CFR 1910.120 , Appendix B (Welch, 1987). The actual level of protection used during the sampling activities will be determined by the SHSO after a site survey has been conducted.

\subsubsection{Equipment Types}

The SHSO (or the health and safety officer provided by the subcontractor/or project manager) will select the type of equipment needed and determine whether additional PPE is needed. Workers will be required to wear appropriate PPE, including steel-toed safety boots for foot protection and approved safety glasses for eye protection as well as latex gloves and an outer disposable suit (Tyvek, Kleenguard) when involved with actual sampling. If air monitoring indicates mercury levels greater than $0.025 \mathrm{mg} / \mathrm{m}^{3}$, personnel will be required to wear half-face respirators with mersorb-type $\mathrm{H}$ cartridges. Hard hats will be required when workers are in the vicinity of the drilling rig or any other heavy-duty equipment, as determined by the SHSO. If increased protection is needed, the protection level can be upgraded as described by Welch (1987).

\subsection{ENVIRONMENTAL MONITORING}

\subsubsection{Chemical Monitoring}

During sampling activities, the work areas will be monitored for organic airborne pollutants, mercury vapors, and particulates. All monitoring will be conducted in accordance with procedures described in the Environmental Surveillance Procedures, Quality Control Program (Energy Systems, 1988).

If any of the following conditions occur, the SHSO will either remove all personnel from the affected area until the conditions abate or upgrade the protection level as described in the Y-12 RCRA Facility Investigation Plan as developed by Welch (1987). 
- Organic vapor levels exceed background conditions for more than one minute.

- Significant dusting ( $>10 \mathrm{mg} / \mathrm{m}^{3}$, which is the permissible exposure limit for nuisance dust; $>5 \mathrm{mg} / \mathrm{m}^{3}$ for respirable nuisance dusts) occurs anywhere in the immediate sampling area.

- The release of airborne mercury vapors occurs exceeding the threshold limit value of $0.05 \mathrm{mg} / \mathrm{m}^{3}$.

The SHSO is responsible for ensuring that organic and/or mercury vapor and particulate monitoring are performed at the site. Monitoring of these parameters should be performed continuously during sampling activities.

There are no specific decontamination procedures required for Level $\mathrm{D}$ protection. Decontamination procedures are thoroughly discussed in the Environmental Surveillance Procedures, Quality Control Program (Energy Systems, 1988). Workers shall be required to follow the standard safety practice of washing hands and face upon leaving the work area and before eating, drinking, smoking, or engaging in any other activity that could cause the ingestion of unwanted materials.

\subsubsection{Radiological Monitoring}

Radiological monitoring will be performed at the CRBAWP. The SHSO will be responsible for performing all radiation surveys at the site and will recommend actions to the subcontractor to be taken to protect personnel working in the area based on the interpretation of these surveys. The frequency of monitoring will be determined by the potential for exposure to radiation at the site. Exposure will be maintained at a level that is as low as reasonably achievable. Procedures for personnel and areal monitoring of radiation, as well as health physics and environmental control standards, are given in Section 70-100-149 of the Y-12 Health and Safety Procedures, Volume 1 (Energy Systems, 1988).

\subsection{EMERGENCY INFORMATION}

\subsubsection{Contingency Plan}

A written contingency plan is required by 29 CFR $1910.120(e)(1)$ and (2) and shall be completed before the commencement of operations on site. In the event of an emergency at CRBAWP, the SHSO or site manager must immediately contact the plant shift superintendent (PSS) and ensure that the plan is followed explicitly. The PSS on duty is responsible for initiating and coordinating all emergency response operations at the $Y-12$ Plant. This plan shall include a form, which provides all essential emergency information and contacts and will be made available to the field team. 


\subsubsection{Emergency Contacts and Reporting Requirements}

In the event of an emergency at the site during the sampling activities, the SHSO will be responsible for maintaining current information on the form and for informing the field team of the form location and means of contacting emergency aid. The SHSO shall also be responsible for reporting any release or other reportable occurrence to the PSS or other responsible party in accordance with DOE Order 5000.3A. 


\section{REFERENCES}

CompuChem Laboratories, 1991. Inorganic Case Summary Narrative, Case 50004, SDG 316535 , Contract $7 / 88$.

Occurrence Reporting Systems, DOE Order 5000.3A.

Fee, G.G., January 18, 1990. Martin Marietta Energy Systems, Inc., letter to R.J. Spence, Department of Energy, Oak Ridge Operations.

Hill, C.C., September 21, 1984. Martin Marietta Energy Systems, Inc., internal correspondence to J.K. Bailey.

Lutz, C.L., May 21, 1990. Martin Marietta Energy Systems, Inc., letter to N.W. Durfee with attachment: System Requirements Document for the Chestnut Ridge Borrow Area Waste Pile.

Martin Marietta Energy Systems, Inc., 1988. Environmental Surveillance Procedures, Quality Control Program, ESH/SUB/87-21706/1, Oak Ridge, Tennessee.

Revis, N.W., et al., 1989. Distribution of Mercury Species in Soil From a MercuryContaminated Site, in Water, Air, and Soil Pollution, V45: pp. 105-113.

Sleeman, R.C., July 24, 1990. Department of Energy, Oak Ridge Operations, letter to E. Leming, Tennessee Department of Health and Environment.

U.S. Environmental Protection Agency (USEPA), 1987. Data Quality Objectives for Remedial Response Activities, EPA 540/G-87-003, March.

U.S. Environmental Protection Agency (USEPA), 1986. Test Methods for Evaluating Solid Waste, SW-846, November.

Welch, S.H., 1987. RCRA Facility Investigation Plant-General Document, Volume I, Y-12 Plant Oak Ridge, Tennessee, Y/TS-352, Vol. I, Martin Marietta Energy Systems, Inc., Oak Ridge Y-12 Plant, November.

Wiggins, K.D., 1988a. RCRA Facility Investigation Plan - General Document, Volume II: Quality Assurance Project Plan, Y/TS-352, Vol. II, U.S. DOE Y-12 Plant, Oak Ridge, Tennessee, Martin Marietta Energy Systems, Inc., Oak Ridge Y-12 Plant.

Wiggins, K.D., 1988b. RCRA Facility Investigation Plan-General Document, Volume III: Data Management Plan, Y/TS-352, Vol. III, U.S. DOE Y-12 Plant, Oak Ridge, Tennessee, Martin Marietta Energy Systems, Inc., Oak Ridge Y-12 Plant. 


\section{REFERENCES (continued)}

\section{Federal Regulations}

29 CFR Part 1910 Occupational Safety and Health Standards. Occupational Safety and Health Administration.

40 CFR Part 261 Method 1311 Toxicity Characteristic Leaching Procedure Appendix II 
APPENDIX A

91-067/0991 


\section{Environmental Requisition Form Used to Submit Samples}

Attached is a copy of an Environmental Requisition (EREQ) form used to submit samples to the Y-12 Environmental and Radiochemistry Laboratory at Building 9769. The requisition number has been removed from the sample sent to you because all the EREQs have unique numbers and are not reassigned.

To facilitate your sampling, our laboratory will prepare sample bottles for your projects. Please call 1 to 2 days ahead of time to allow enough lead time to prepare the bottles. At the time of your first sample submission, personnel at our Receiving desk will provide you with enough EREQs to complete your projects. The Receiving Group will also assist you in filling out the EREQ.

You will need to forward a copy of your sampling and analysis plan to either Bill Harper or myself before sampling begins. This will allow the laboratory to provide the level of quality assurance necessary to meet the needs of your projects.

Per our discussion, the analyses you requested will need to be entered on the EREQ using the following determination codes (DCs):

$\begin{array}{ll}\text { Complete TCLP } & \text { DC } 346 \\ \text { Uranium, total } & \text { DC } 142 \\ \%{ }^{235} U & \text { DC } 139 \\ \text { PCBs } & \text { DC } 221\end{array}$

If I can be of further assistance, please call me at 574-2904.

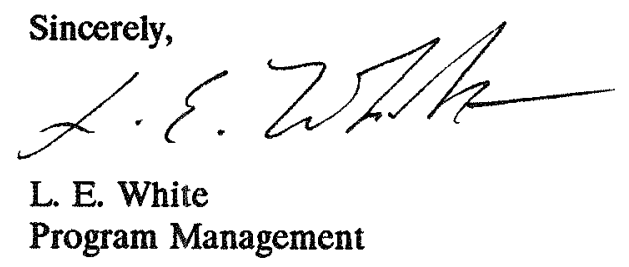

LEW:esl

Attachment

cc/att: J. G. Dorsey

W. L. Harper

R. J. McElhaney

A. L. Yeager 
REQUISITION FOR ENUIRONMENTAL ANALYSES

FEqu3 2t:2n: AOE439

Eir:

No. Battles:

Eriv Sanf i: Code: SamEle DEz::

Sanfie Loc:

Date:

Time:

By:

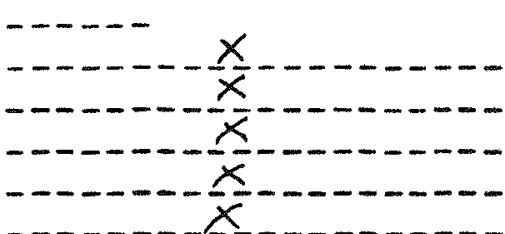

Fequeter. Eadge:

Name:

Addr:

Pharie:

FEF ID:

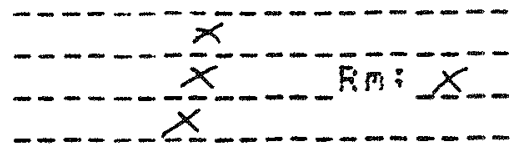

Cherge Code:

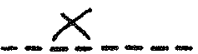

Hand ling:

x

No. Samfles if

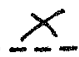

Remarks:

$x$

iFor mLltifie samele locatians, fut MULT under Eamfle lac end list lacatiane.

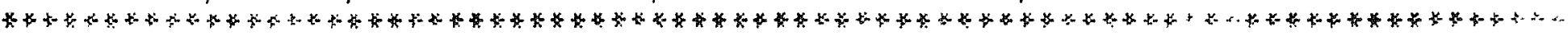

Please request determariatachs by DC cades.

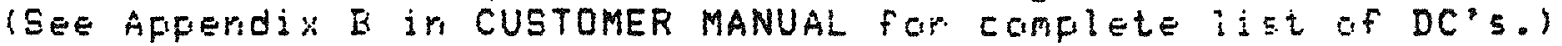

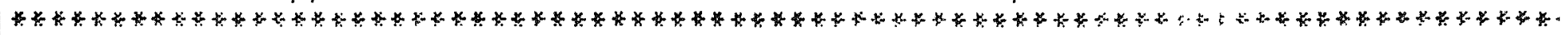

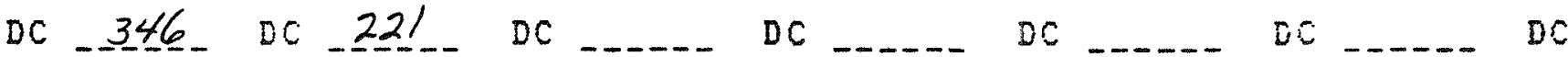

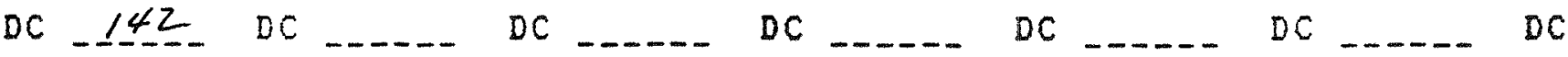

$D C \ldots 139 . D C \ldots D C \ldots D C \ldots D C \ldots D C$

ather … ANy Request to which No DC Exists -

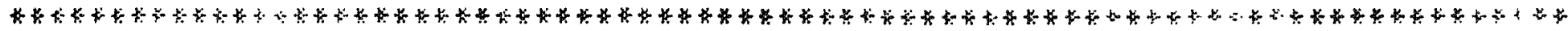

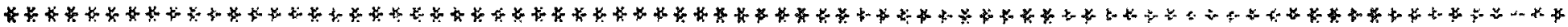

If more than orie sample. Flease idertify eamples in thi gface below.

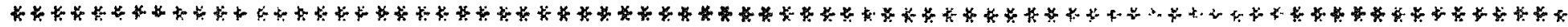

SUE SAMELE 00:

SUE BAMPLE 002

SUE EAMPLE 003

SUE SAMFLE 004

SUE GAMFLE OOS

SUE SAMFLE 006

SUE BAMFLE 007

SUE इAMPLE 008

SUE BAMFLE 200

SUE SAMFLE 010
SUE SAMFLE O11

SUE SAMPLE O1Z

SUE SANFLE 013

SUE SAMPLE O14

SUE SAMFLE O15

SUE SAMPLE OIS

SUE SAMPLE O17

SUE SAMFLE I15

SUF SAMFLE 017

SUE SAMFLE OEO

U6: 1700: 2 $3-70:$ 


\section{APPENDIX B}




\section{Comprehensive Health and Safety Plan}

Site-specific Checklist

\section{Packet Cover Sheet}

Required inspection frequency:

Purpose of inspection:

Date inspected:

Inspected by:

(signature and signed initials)

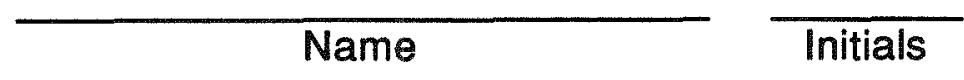

Inspected by:

(print name and printed initials)

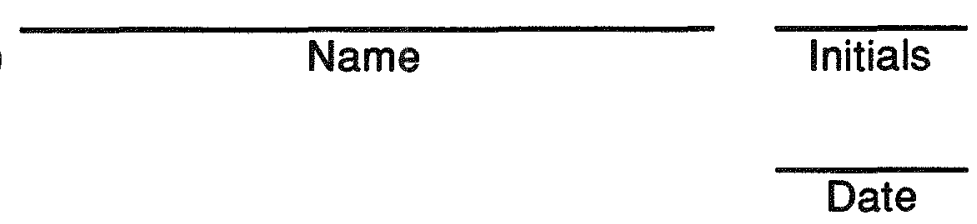

Reviewed by (signature):

Name

Reviewed by (print name):

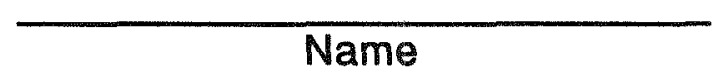

Packet contents:

Site-specific checklist for

\section{Site name}

Revision , Revision date

Detailed checklist (initial if used):

RCRA Satellite Accumulation Area, Revision Initials

RCRA 90 Day

Accumulation Area, Revision Initials 
Comprehensive Health and Safety Plan

Site-specific Checklist

Site Organization (2.0)

\section{Eneroy Systems personnel}

RAP Coordinator: TBD

Project Engineer: TBD

Construction Engineer: TBD

RAP Health \& Safety

Coordinator: TBD

Contacts:

Industrial Hygiene

Health Physics

Safety

Waste Management

Quality Assurance
Subcontractor personnel

Project Manager: TBD

Field Project Manager: TBD

Health \& Safety Officer: TBD

Site Hazard Characterization (3.0)

Site location: Chestnut Ridge Borrow Area Waste Pile east end of Y-12 Plant reservation.

Site history: Mercury contaminated soil from East Fork Poplar Creek place on Civic Center and removed to present site.

Suspected/Known location of chemicals/materials onsite: Mercury, other metals including uranium, organics, and PCBs.

Site map attached

Yes

Site and/or task-specific Monitoring/Work Plan attached? Yes 
Comprehensive Health and Safety Plan

Site-specific Checklist

Chemical Hazards (4.1)

\begin{tabular}{|c|c|c|c|c|c|}
\hline $\begin{array}{l}\text { Suspected } \\
\text { chemical }\end{array}$ & $\begin{array}{l}\text { Estimated } \\
\text { quantity (units) }\end{array}$ & $\begin{array}{l}\text { Exposure } \\
\text { limits }^{a}\end{array}$ & Carcinogen & Teratogen & $\begin{array}{l}\text { Lower flammable } \\
\text { limits (\% in air) }\end{array}$ \\
\hline $\begin{array}{l}\text { mercury } \\
\text { vapors }\end{array}$ & slight & $0.05 \mathrm{mg} / \mathrm{m}^{3}$ & & & NA \\
\hline $\begin{array}{l}\text { volatile } \\
\text { organics }\end{array}$ & none & $\begin{array}{l}>5 \mathrm{mg} / \mathrm{m}^{3} \\
\text { background }\end{array}$ & & & NA \\
\hline
\end{tabular}

Standard operating procedures: Energy Systems Environmental Surveillance Procedures

Engineering controls possible: Waste containerized and soils covered by plastic sheeting

Administrative controls possible: Site access restricted from aeneral public

Monitoring methods to be used

Site: HNu - Beta/Gamma Detector - Jerome Mercury Vapor Analyzer

Personnel:

Specific labeling requirements of site-generated waste: $214 \mathrm{~B}$ tags on drums

${ }^{a}$ Give most protective exposure limit from OSHA (PEL), ACGIH (TLV), or MSDS 
Comprehensive Health and Safety Plan

Site-specific Checklist

Chemical Hazards (4.1) (continued)

Chemical-specific disposal requirements:

Safety Hazards $(4.2,4.3,4.7,4.12$, and 4.13)

Any cutting-welding-hot work to be done onsite?

Yes No

Describe:

Any flammable/combustible materials stored onsite?

List materials, quantities, and location:

Materials

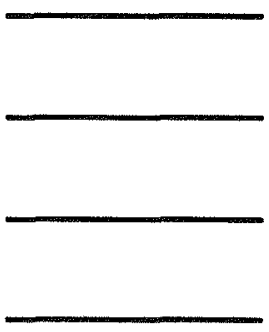

Quantities

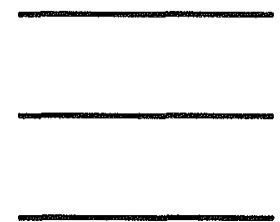

Flammable materials being dispensed from drum? Drum grounding present?
Locations

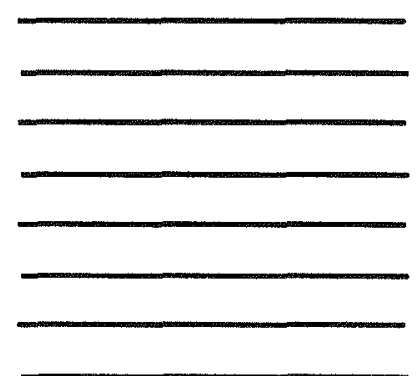

Yes $/$ NO

Yes /No

Yes/No

Fire protection equipment present?

Descriptions and locations: 
Comprehensive Health and Safety Plan

Any other fire hazard present?

Describe:

Confined space entry required?

Risk type

Oxygen deficiency/enriched environment?

Yes No

Explosive atmosphere?

High / Low

Toxic atmosphere?

Confined Space monitoring schedule:

If hazardous work permit required (high risk) then list number - and attach to checklist.

Electrical shock hazard?

Yes/No (specify)

Voltage

Current

If Yes, then list EWP\# and attach to checklist.

Location of hazard:

Protective equipment (see Personal Protective Equipment Checklist):

Current illumination levels greater than $5 \mathrm{ft}$-candles?

Additional illumination needed?

Remarks: 
Safety Hazards (continued)

Heavy equipment in use?

Site Name:

Operators are certified to operate?

Heavy equipment in use - describe: Small portable drill rig

Methods of site communication: TBD

Portable radio (walkie/talkie)

Cellular phone

Warning horn

Visual hand signals

Other safety hazards or comments: 


\section{Comprehensive Health and Safety Plan}

Site-specific Checklist

lonizing Radiation (4.4)

Primary contaminating isotope(s)

Site location

Containment/storage method

Radiation type

Dose rate (maximum)

(average)

Worker dose limit

Contamination level (fixed)

(removable)

Airborne contamination concentration

Personnel monitoring required?

Site monitoring required?

Water contamination potential?

Unrestricted airborne contamination release potential?

Hazardous work permit required?

Applicable detailed checklist?

Health Physics coverage?

Special task operation requirements
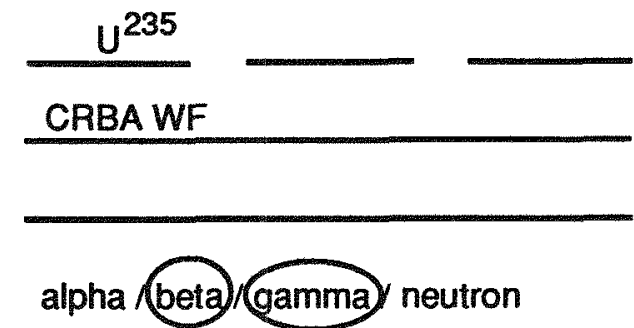

TBD

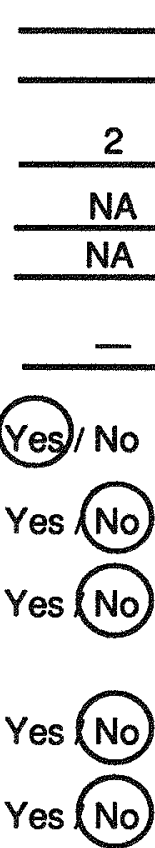

mR/h@ meter(s) $\mathrm{mR} / \mathrm{h}$

$\mathrm{mR} / \mathrm{h}$

A $d p m / 100 \mathrm{~cm}^{2}$

$\mathrm{dpm} / 100 \mathrm{~cm}^{2}$

$-\mu \mathrm{Ci} / \mathrm{ml}$

Yes / No / NA

Continuous Intermitten

Welding/cutting/brazing Grinding/chipping Hydraulic/air hammer operation Dusty conditions (sweeping, vacuuming, etc.) Equipment decontamination/free release

Remarks: 


\section{Comprehensive Health and Safety Plan}

Site-specific Checklist

$$
\text { lonizing Radiation (continued) }
$$

\section{Site Monitoring}

Airborne contamination sampling required?

Frequency?

High volume area samples required $\left(\sim 45 \mathrm{ft}^{3} / \mathrm{min}\right)$ ?

Low volume area samples required ( $\sim 40$ LPM)?

Personnel samples required (breathing zone $\sim 8$ LPM)?

Special sampling procedures (specify):

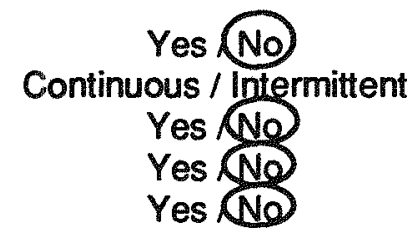

ous / Intermittent

Yes $\mathrm{NO}$
Area radiation monitors required?

Continuing removable contamination (smear) surveys required?

Continuing radiation dose rate surveys?

\author{
Yes No \\ Yes NO
}

Yes / No / NA

\section{Personnel Monitoring}

Radiation monitoring required?

Whole-body personnel dosimetry required?

Extremity dosimetry required?

Pocket dosimeters required?

Baseline bioassay required?

Urinalysis/bioassay@ task completion?

Whole-body count @ task completion?

Area radiation monitoring required?

Perimeter TLDs required?

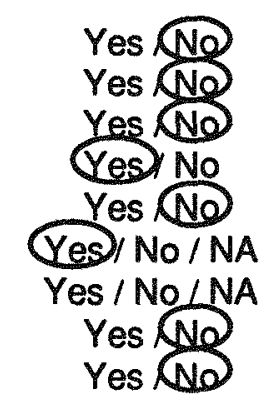

Special radiation work area requirements

Temporary/permanent contamination-zone boundary

Herculite work area base pad

Work area exit step-off pad

Contamination-zone laundry bag

Personnel frisker located at C-zone exit

Rad-trash container

Ventilation requirements (specify)

Portable HEPA filter unit

Negative-pressure tent

HEPA-filtered lab hood 


\section{Comprehensive Health and Safety Plan}

Site-specific Checklist

Non-lonizing Radiation (4.5)

Source of ultraviolet radiation (other than the sun) present?

Describe protective measures taken: 
Comprehensive Health and Safety Plan

Site-specific Checklist

Non-lonizing Radiation (continued))

Are laser devices present?

Yes No

List laser class rating:

Describe protective measures taken:

Are ultrasound sources present?

Yes/No

Describe protective measures taken: 


\section{Comprehensive Health and Safety Plan}

Site-specific Checklist

Biological Hazards (4.6)

Location onsite

Source of contamination

Existing containment?

(specify):

Type of organism (specify) virus bacteria fungus parasite

Site monitoring required

Personnel monitoring required

Sampling required (personnel/site)

Protective clothing required (see detailed checklist)

Additional administrative controls (specify):

Yes /No
Yes /No
Yes /No
Yes /NO
Yes /No

Remarks: 
Comprehensive Health and Safety Plan

Site-specific Checklist

Temperature Extremes (4.8)

Temperature extremes present (hot/cold)?

Average daily high temperature (during work shift) ${ }^{\circ} \mathrm{F} /{ }^{\circ} \mathrm{C}$ Average daily low temperature (during work shift) ${ }^{\circ} \mathrm{F} /{ }^{\circ} \mathrm{C}$ Average wind speed MPH Microenvironment level Yes / No Cloudy/Sunny $1 / 2$

Precautions (specify):

Cooling/heating equipment needed:

Potential/Known noise sources? ${ }^{b}$

Noise Hazards (4.9)

Noise source

Drill Rig
Sound level in $\mathrm{dB}(\mathrm{A})$

Yes) No

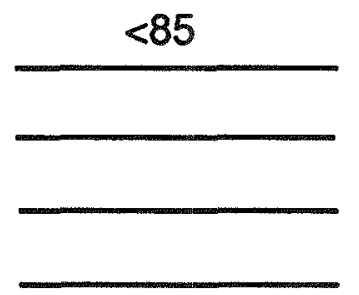

Noise equal to or greater than $85 \mathrm{~dB}(\mathrm{~A})$ (hearing protection required)?

Measures taken to reduce levels: ear plugs

bNo sound level shall exceed $110 \mathrm{~dB}(\mathrm{~A})$ 
Comprehensive Health and Safety Plan

Site-specific Checklist

Vibration Hazards (4.10)

Vibration sources present?

Vibration sources:

Measured vibration frequency $\lambda$

Describe protective measures taken:

Sanitation needs?

Potable water needed?

Nonpotable water used?

Eating, drinking, and smoking permitted?

Housekeeping status?

Where?

Toilet facilities available?

Location and number:

Washing facilities available? Location:

Change rooms needed? (specify): 
Comprehensive Health and Safety Plan

Site-specific Checklist

Job Exposure Risks

List each job function or activity that will occur in the contaminated zone and the exposure risks involved:

Job/Activity: Sampling Team Leader

Exposure risks: mercury vapors, dust heat/cold extremes

Job/Activity: Soil sampling team member

Exposure risks: same as above

Job/Activity:

Exposure risks:

Job/Activity:

Exposure risks: 


\section{Site Name:}

\section{Comprehensive Health and Safety Plan}

Site-specific Checklist

\section{Personal Protective Equipment (5.0)}

\begin{tabular}{ll}
$\begin{array}{c}\text { Lecation } \\
\text { Contaminated Zone }\end{array}$ & $\begin{array}{c}\text { Job function } \\
\text { Team Members } \\
\text { Drill Crew }\end{array}$ \\
\hline \\
\hline \\
\hline Decontamination Zone \\
\hline
\end{tabular}

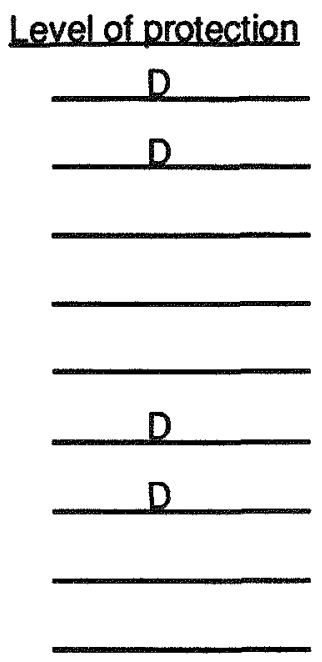

Specific protective equipment for each level of protection (specify materials of construction):

Personal Protective Equipment List

Level

\section{Supplied Air Respirator SCBA}

Powered Air Purifying Respirator Full-Face Air Purifying Respirator Hali-Face Air Purifying Respirator Hard Hat Encapsulating Chemical Resistant Suit Inner and Outer Chemical Resistant Gloves

Chemical Resistant Safety

Boots/Shoes

Face Shield

Cooling Unit

Coveralls

Disposable Glove or Boot Covers

Anti Vibration Gloves

Ear Muffs or Plugs

Escape Mask

Safety Glasses or Goggles
A

B

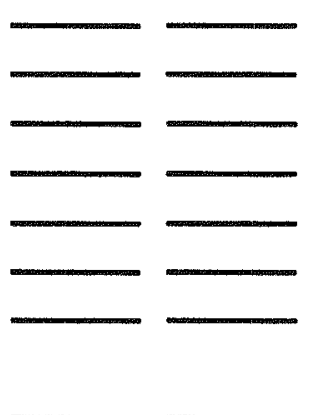

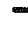

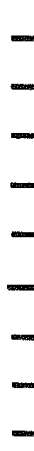

c

D
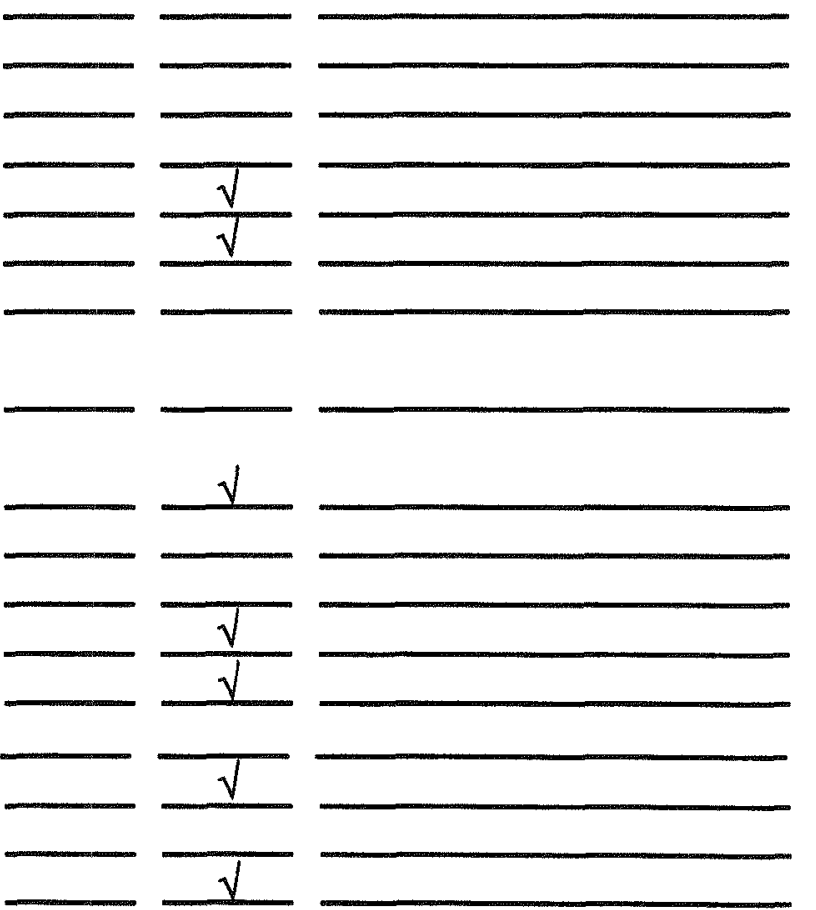
Comprehensive Health and Safety Plan

Site-specific Checklist

Waste Management/Disposal (6.0)

Is a project waste management plan (PWMP) prepared?

Is the PWMP attached to this checklist?

Spill Containment and Control (7.0)

Will any liquid materials be handled during activities onsite?

Is spill containment and control plan attached?

\section{Emergency Management/Response (8.0)}

Emergency Contacts:

Plant Shift Superintendent

Plant Emergency Director

Site Construction Engineer

Emergency Medical Services

Subcontractor Project Manager

Emergency evacuation route map and procedures attached?

Employees aware of the various emergency signals?

List emergency communication procedures: 
Comprehensive Health and Safety Plan

Site-specific Checklist

Decontamination/Site Control (9.0)

Method of marking separation between contaminated, decontaminated, and clean zones (Include a site map complete with work zones):

Flagging or ribbon only necessary

Barriers in place, intact, and appropriate?

Yes / No

Entry/exit logs required?

Yes/No

Personnel properly signed in?

Personnel properly signed out?

Site posted information/notification present?

Yes/No

Site properly posted?

Site properly guarded?

Yes / No

Yes / No

Yes/No

Access control required?

Is body of water present? (If yes, 29 CFR 1926.106 applies.)

Yes/No

Yes/No

Yes/No

Decontamination procedures for:

Exit from Contaminated

Zone through Decon Zone and enter Clean Area

None

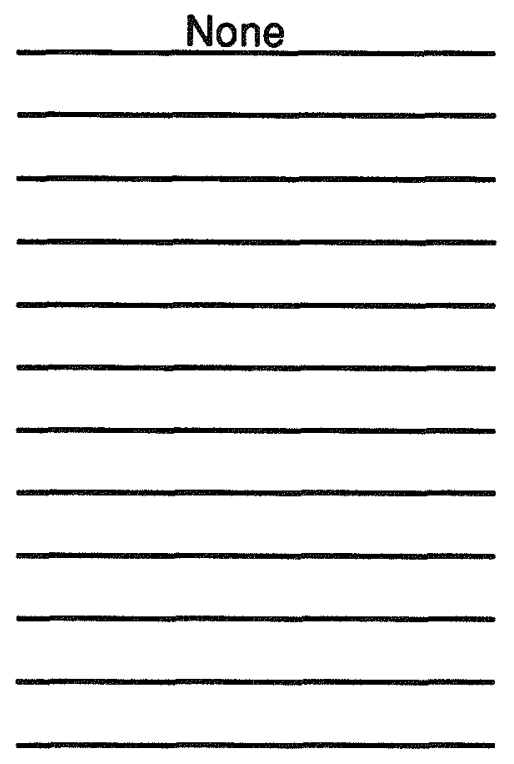

Exit from Contaminated

Zone and rest break in

Decon Zone

None

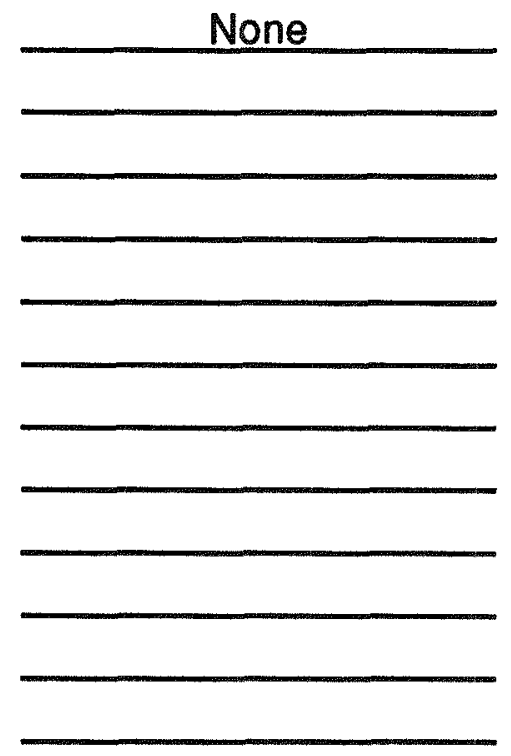

Decon during emergency medical response

None 
Comprehensive Health and Safety Plan

Site-specific Checklist

Record Keeping Requirements $(12,13)$

Confined space entry

Oxygen level measurements

Hazardous work permit

Excavation permit

Flammability measurements

Combustible gas

lonizing radiation

Worker dose

Contamination level

Airborne contamination level

Hazardous work permit

Non-lonizing radiation

UV level measurements

Microwave level measurements

Laser power level measurements Biological

Personnel exposure monitoring Electrical

Tag-out records

Electrical work permits

Temperature Extremes

WBGT measurements

Daily temperature/wind speed Noise

Area monitoring

Personnel monitoring

Vibration

Source measurements
Required

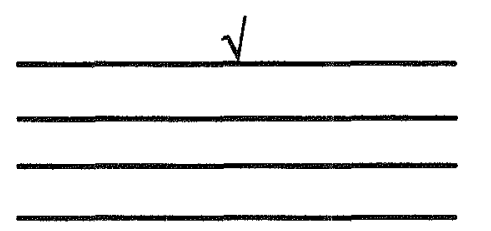

Present/Available
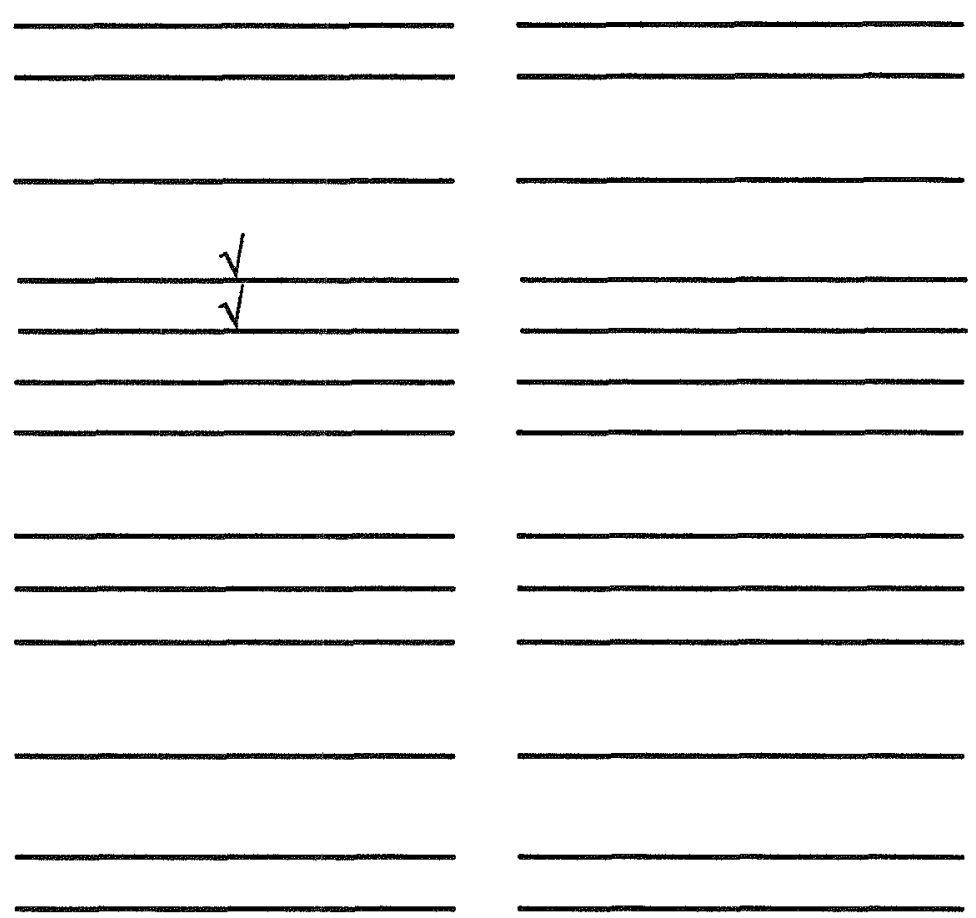
Comprehensive Health and Safety Plan

Site-specific Checklist

Record Keeping Requirements $(12,13)$ (continued)

Required

Present/Available

Illumination

Area foot-candle measurements

Personnel Medical Monitoring

Safety/Emergency Response

OSHA accident reports

Accident/incident reports

Personal Protective Equipment

Inspection of:

Clothing

Respirators

Gloves

Boots

Waste Disposal Manifests

Waste Characterization Records

Spill Incident Reports

Training of Employees

Entry/Exit Logs

Hazardous work permits

Electrical work permits
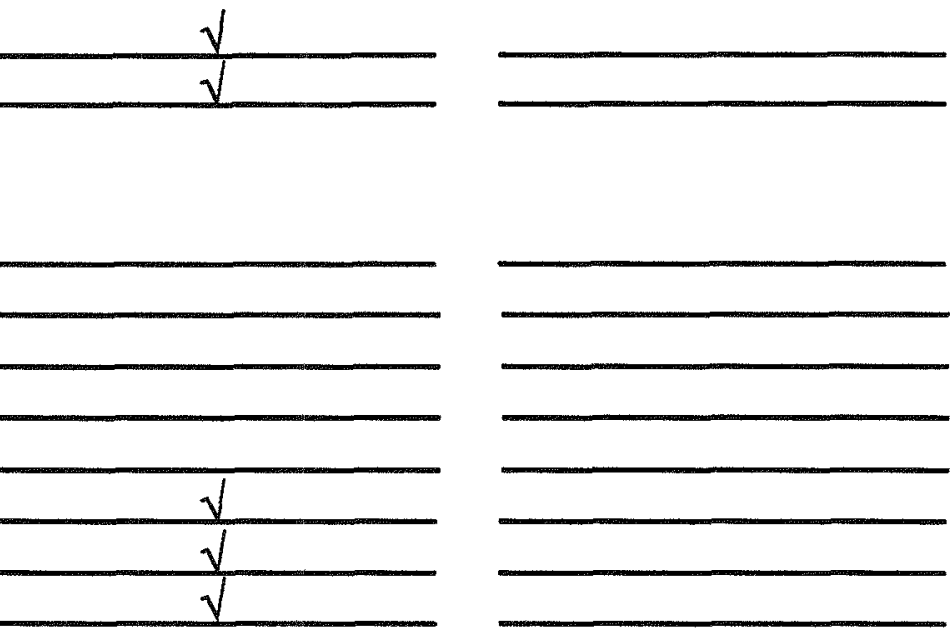
Page 20 of 21

Revision:

Revision Date:

Site Name:

Comprehensive Health and Safety Plan

Site-specific Checklist

Audit Deficiencies and Corrective Actions 


\section{Comprehensive Health and Safety Plan}

Site-specific Checklist

On-the-Job Training (OJT) Documentation

Required OJT Frequency:

Job Category of OJT Recipient:

Date of OJT:

OJT received by:

(signature and signed initials)

$\longrightarrow$ Name Initials

OJT received by:

(print name and printed initials)

Name

Initials

Date

OJT supervised by (signature):

Name

OJT supervised by (print name):

Name

Date

Packet Contents:

Site-Specific Checklist for

(Site Name)

Revision Revision date 


\section{DISTRIBUTION}

1. J. M. Eaton/R.L. Johnson, Jr.

2. B. E. Fuhrer

3. J. B. Hunt

4. S. L. Lankford, DOE

5. M. A. McKinney

6. L. W. McMahon/R. R. Painter

7. J. L. Sager, DOE

8. S. H. Welch

9. J. L. Williams

10. W. G. McMillan

11. A. K. Lee/DOE-OSTI (4)

12. Y-12 Central Files

13. File - EMD - RC 